\title{
SIMALOEREESCHE TEXTEN
}

\author{
DOor H. T. DAMSTÉ.
}

In November 1854 bezocht de toenmalige resident van Tapanoeli F. H. J. Netscher "Poeloe Si-Maloe», het «Hog-island der Engelsche zeekaarten».

In zijn dus getiteld opstel (Tijds. I. T. L. Vk. V 403) zegt hij, dat de taal er volkomen gelijk is aan die der Maleiers uit de Padangsche Bovenlanden, waardoor hij gemakkelijk in het bovenlandsch maleisch met de inwoners kon spreken. Verder teekent hij echter aan: "Wel heeft men eene andere taal, bij "hen de landstaal genoemd, doch dit is eene vermenging van »Atjehneesch en Maleisch; deze wordt op de Noordoostkust "minder gesproken, dewijl daar geene Atjehneezen gevestigd zijn.»

K. F. H. Van Langen, die in begin 1881 een reis makkte naar Simaloer, meende (Tijds. I. T. L. Vk. XXVII 383), dat de bevolking tot den Niasschen stam zou behooren. Echter sprak zij "eene van het Niasch onderscheiden taal, hoewel vele „woorden op een nauwe verwantschap met die taal duiden.»

In het Tijds. Ind. Aardr. Gen. $1^{\mathrm{e}}$ jaarg. afl. III bl. 1 noemde Van Langen eene volksoverlevering, verklarend "het vreemde »verschijnsel, dat de bevolking der districten Si Maloer, Tapah »en Lakoön eene geheel andere taal spreekt dan die der dis»tricten Salang en Si Goelei, waar het Niasch de volksspraak »is. Ook verklaart zij ons het feit, dat de bevolking van $\mathrm{Si}$ "Maloer uit twee hoofdbestanddeelen is samengesteld, de oor»spronkelijke bevolking of aborigenen met eene afzonderlijke »taal en de Niassers, die hun eigen taal spreken. Verwant»schap der door haar» (de oorspronkelijke bevolking) "gesproken staal met eenige andere Indische konden wij niet opmerken, »doch het kwam ons voor, dat vele woorden uit het Niasch »daarin schenen opgenomen. Of dit nu te wijten is aan de versmenging der oorspronkelijke bevolking met de Niassche dan »wel aan hare stamverwantschap daarmede, durven wij niet „beslissen.» 
«Sommigen beweren wederom, dat de aborigenen van $\mathrm{Si}$ "Maloer tot het Gajoesche ras behooren "'.

Dezelfde auteur schreef in zijn "Atjèhsch Westkust» (T. A. G. 2 $2^{\mathrm{e}}$ Reeks V 511): "Het Simaloereesch is waarschijnlijk seen dialect van het Niasch, waarin vele Maleische woorden zijn opgenomen. Hoewel volgens de hier loopende sage de „Simaloeërs tot den Gajoeschen volksstam behooren, zoo kun»nen zij toch een bewoner der Gajoelanden niet verstaan en »schijnt hunne taal zich zelfstandig te hebben ontwikkeld. "Volgde een lijstje van 23 woorden, blijkbaar ontleend aan de taal van Tapah en Simaloer maar niet altijd juist afgebeeld en vertaald.

L. C. Westenenk stelt vast in Bijdr. T. L. en Vk. N.-I. LVI 302: dat Netscher verkeerdelijk de landstaal eene vermenging van Atjèhsch en Maleisch noemde; dat een medegenomen Niasser zich niet kon verstaanbaar maken aan lieden van Noord Simaloer, waar volgens van Langen het Niasch de volksspraak zou zijn; en eindelijk, dat de Gajō niet wordt verstaan, maar dat vele eilanders Minangkabausch en Atjèhsch spreken.

Inderdaad, de kennis van Atjèhsch en Minangkabausch is op het eiland algemeen, en met Niasch kan men er niet terecht. Maar juist was van Langen's beweren, dat de bevolking in het Zuiden eene andere taal spreekt dan die in het Noorden.

Het door Westenenk gegeven woordenlijstje betreft de «léng banò», de taal van de districten Tapah en Simaloer van de Zuidelijke, tevens grootste en minst dun bevolkte helft van het eiland.

Een uitvoeriger maar weinig betrouwbare woordenlijst is later samengesteld door geëmployeerden van de Java bosch exploitatie maatschappij. ${ }^{2}$

Van half Maart tot half Juni 1912 verbleef ik te Sinabang als controleur van de toen nieuw geschapen onderafdeeling "Simeuloeë» (Districten: Tapah, Simeuloeë, Leukoeën, Salang en Sigoelè, met resp. $1566,828,152,111$ en 631 , of totaal 3288 mannen, of $5350,2660,471,314$ en 2067 , of totaal 10.862 zielen) ${ }^{3}$.

Ook ik heb toen vooral omtrent de «léng banò» gegevens ingewonnen.

1 Omtrent dat beweren vergelijke men Dr. Snouck Hurgronje: „Het Gajöland en zijn bewoners" bl. 74 .

2 Over die woordenlijst wordt gehandeld in de Notulen der Vergaderingen van het Bataviaasch Genootschap 1912-1913 bl. 5 en 62 .

3 Den $4^{\text {en }}$ Januari 1907 kwamen langs de Zuidkust 1818 menschen door een vloedgolf om het leven. 
V. w. b. de taal van Sigoelè (inheemsch Sichoelè), de "wali banoeah, 1, was mijn oogst slechts gering. Hoewel de bevolking er zelf meent van Niassche origine te zijn, is in wat ik verzamelde geen Niassche taal te herkennen. Hoe het met Salang en Leukoeën (inheemsch Lěkòn) is gesteld, weet ik mij niet te herinneren. Het woordenlijstje van de Java bosch expl. $\mathrm{m}^{\mathrm{ij}}$ rekent Salang tot het taalgebied van Tapah en Simaloer, maar van Langen groepeerde het bij Sichoelè, en zoo deed ook $1^{t}$ Hotz. (Vide onderstaande noot.)

Hieronder wordt enkel gehandeld over de "léng banò of «landstaal» van Tapah (inheemsch Oelaò of Dèfajan) en Simeuloeë (Atj.), Simaloer (Mal.) of inheemsch: Simoeloel.

Eene geschrevene litteratuur bestaat daarin niet. Er worden kalme minneliedjes gezongen (nanga-nanga). Moeders en zorgzame zusjes zingen wiegeliedjes (ilala). Men geeft elkaar raadsels op (taě-tae, lett. "antwoorden»). Maar vooral zijn het vertellingen (inafi-nañ) waarmee men elkaar den tijd kort; eerstens dierenverhalen, en verder geschiedenissen van de stamvaderen: Lamborè $\grave{s}^{s}$ die het eiland wilde door midden zagen, Lasènga ${ }^{s}$ die hem zulks belette, Lafòè en Lafōng Lasali. Voor ernstiger litteraire genietingen speelt de polyglotte bevolking leentjebuur bij Atjèher en Minangkabauer.

De intieme vertrouwdheid der Simaloereezen met het Atjèhsch en Minangkabausch is natuurlijk niet zonder invloed gebleven op de landstaal. Deze is als doorspekt met Atjèhsche en nog meer Minangkabausche woorden en vormen. Dat zal er stellig niet op verbeteren, sinds de vestiging op het eiland van houtaankapondernemingen, het geregeld bezoek tegenwoordig van pakket- e. a. booten, de oprichting te Sinabang van een Gouvernements Inlandsche school, en de vestiging aldaar van een controleur met een staf van Maleische beambten en politiedienaren.

Waar dus de taal gevaar loopt, is de publicatie van ondervolgende texten waaruit $\mathrm{zij}$ in haar tegenwoordigen staat is te kennen, stellig wel gerechtvaardigd.

Doen we voorafgaan eenige theorie, die voor hen, die in bestuurs- of andere practische betrekking op Simaloer belanden,

I Blijkens Not. B. G. $1912-1913$ bl. 62 heeft de 2e luit. Inf. G. D. E. J· Hotz ook van de taal van Sigoelè on Salang een woordenlijstje verraardigd en aan het Bat. Genootschap gezonden. 
wellicht van nut kan zijn, om zich op taalgebied vlugger te orienteeren.

De Simaloerees kent geen eigen letterschrift. In Arabische karakters wordt enkel Maleisch en Atjèhsch geschreven. De eigen landstaal wordt enkel gesproken.

Daarbij valt de meeste klemtoon op de laatste lettergreep, maar belangrijk is hij gewoonlijk niet. In de volgende zinnen heb ik gecursiveerd wat eenige nadruk erlangde:

Nga sara Toeankoe Manggarang èrè , banònè tè Poelò Banjas, mamòti-mamòtijah mès $L \bar{o}^{s}$ Simoeloel. Lèntōs i $a$ ès $\mathrm{ba}^{s} \bar{o}^{s}$, nipanggél sagalò radjò-radjò, léngnè : " $\mathrm{E}^{s}$ dè $\bar{o}$ èrè nga $n a^{s}$ fěsang $\grave{e}^{s}$ bach $a^{s}$ banòmè-rè, mièna $a^{s}$-èna $a^{s} \mathrm{a}^{s} \bar{o}$.

Klankwisseling.

Aan het begin van een woord wisselen $f$ en $b ; d$ en $r ; s$ en $t j$; en aan het begin ook van een $2^{\text {de }}$ lettergreep wisselen $h$, ch en $k$. Fa, $\mathrm{fa}^{5}, \mathrm{fa}^{s} \mathrm{al}$, falōng, fanò, fæll, fěngi, féré, foeha, zouden meer beschaafd en ouderwets klinken dan ba, bas, basal, balōng enz. In dezelfde verhouding zouden staan raï, ralan, ran, rěman, rò , roema ar enz. tot daï, dalan, dan enz.; evenzoo chaě, chěbau, oechoen, chachan enz. tot kaě, kěbau, kōn en kahan. Men hoort echter het zoogenaamd fijne en grove overal dooreen gebruiken, dus groot schijnt het verschil niet te zijn.

Lettergrepen die soms open zijn, worden een ander maal gesloten met een geaspireerde $h$; en vaak opent of sluit men een met een klinker beginnende of eindigende lettergreep met een sterk geprononceerde gutturale $k$, en laat dat een volgend maal weer na. Zoo is tainèh $=$ tai $^{\text {s }}$ è $=$ zijn hoogte of de hoogte ervan. Tainèh zou men meer zeggen in het district Tapah, terwijl tai'nè meer Simaloereesch zou zijn; maar niet steeds zijn die verschillen te verklaren enkel uit een verschil in landaard. Eén zelfde spreker laat zich betrappen op dergelijke - ik zou haast zeggen: inconsequenties, want de variaties kwamen mij voor te zijn geheel willekeurig. Verschil in beteekenis als gevolg van het al dan niet 'gebruiken van $h$ of s liet zich voor mij niet ontdekken, evenmin als een regel volgens welke zou worden tewerkgegaan.

De uitgang $-a s$ wisselt met $-a j$ of $a i^{\text {s. }}$ Zoo hoort men toeas, lěpas, atas, fòras, nas, naast toeaj, lěpaj, astaj, bòraj, naj. 
$\grave{O}$ wisselt met $\breve{e}$ : Mòn, gevolgd door ng, geeft, waar de klemtoon steeds valt op de eindlettergreep begrijplijkerwijze měněng. Naast mamòlěng hoort men mamělěng. De samenstelling dò-fěngi geeft dòfòngi.

Voorbeelden dat de $o$ naburige klinkers overweldigt vindt men in mòrò $\mathrm{s}=$ mèrò $\mathrm{s}$, oewòlòfil $=$ oewila òfil (denk ik ten minste).

Dat $\breve{e}$ verandert in $e ́$ of $i$ ziet men in fěl, waarvan is afgeleid òfél of òfil.

Aan het eind van een woord verandert $\grave{e}$ bij aanhechting van $n g$ 'soms in é; zoo wordt jè : jéng, nè: néng.

Ook met $i$ is dat somtijds het geval: fěngi wordt fěngéng, achi: achéng.

$A \grave{e}$, $a i$, en $i a$ worden vaak saamgetrokken tot $\grave{e}$ : Daifa ${ }^{s}=$ dèfa $^{s}$, mainihi $=$ mènihi, maè $=$ mè, siamònan $=$ sèmònan , $\operatorname{dia}^{s} \bar{o} \mathrm{~h}=\mathrm{dè}^{\mathrm{s}} \overline{\mathrm{o}} \mathrm{h}$, nialinafian $=$ nialinafèn.

Van omzetting van klinkers uit verschillende lettergrepen levert een voorbeeld: Sòdibòngi, van sidòfòngi $=$ eergisteren.

Werkwoordvervoeging.

Stamwoordelijke werkwoorden worden vervoegd, d. w. z. zij laten zich tot één verbinden met de ervoor geplaatste persoonsexponenten.

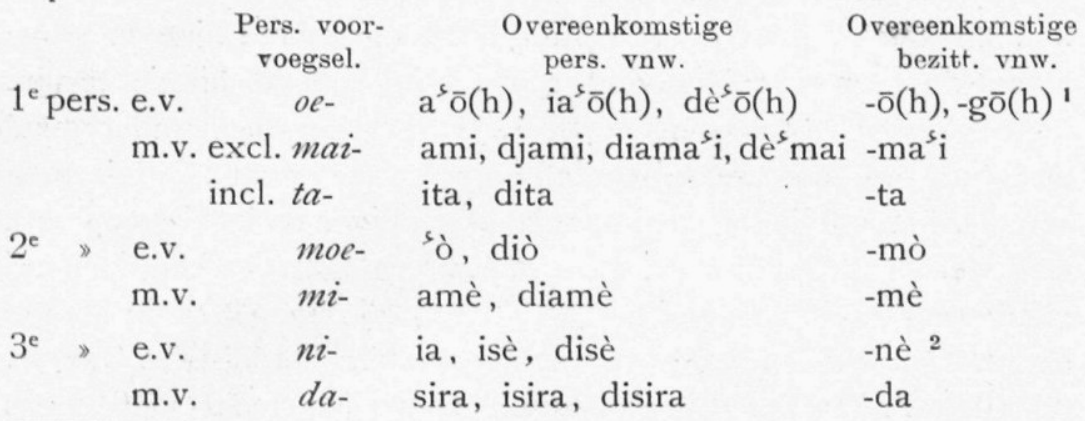

1 Tusschen een op een klinker eindigend woord en het daaropvolgend bezitt. v.n.w. $1^{\circ}$ p.e. v. $\cdot \bar{o} h$ of $\cdot g \bar{o} h$ wordt ingeschoven de neusklank $n g$, terwijl vóór - $t a$ het woord wordt gesloten met een $n$. Veelal gaan die nasalen vergezeld van een gutturale $k$, die soms er vòòr komt en soms er achter.

achingōh $=$ mijn broer

$\therefore$ loemangōh $=$ mijn huis tidaònggōh $=$ mijnn verzoek aratòng $g^{s} \mathrm{~h}=$ mijn bezit ata $^{s} n g g \bar{o}=$ mijn menschen

2 -nè fungeert soms ook als nadrukwijzer. Verrijkt met den nadrukwijzer -ia, wordt de combinatie -nè-ja soms samengetrokken tot -nja:

alal chléng-chléng-nja $=$ de mosselschelpen. 
Oechaj

Oeprang s’ò

Maitoesas s̀̀

Taba ja radjòsnta èrè

Moeda sioe $^{s}$ antě ${ }^{s}$, moean; moeda na ${ }^{5}$, moean

Mitoe ${ }^{s}$ as $a^{s} \bar{o}$

Ara mila?

$\mathrm{Nijōb}$ angèn

Fadō nitaě wòōnèja

Nianengiah

Nintōò

Daòlěng mès loema

Dana'eun annèja
$=$ Ik wil niet.

$=\mathrm{Ik}$ beoorloog $\mathrm{u}$.

$=\mathrm{Wij}_{\mathrm{ij}}$ laten u los.

$=\mathrm{Wij}$ stellen hem aan tot onzen vorst hier.

$=$ Wilt ge straks eieren, ge eet ze; wenscht ge kiekens, ge eet ze.

$=$ Laat mij los.

$=$ Weet gij lieden ervan ?

$=$ Het waait.

$=$ Hij antwoordde niet, haar broer.

$=$ Hij zweeg.

$=$ Hij slaat $\mathrm{u}$.

$=\mathrm{Z}_{\mathrm{ij}}$ keerden huiswaarts.

$=\mathrm{Zij}$ dienden op zijn eten.

Uit de gegeven voorbeelden blijkt, dat zoo bedrijvende als onzijdige werkwoorden worden vervoegd. Straks zullen we zien, dat de afgeleide causatieve $a$-vormen mede worden vervoegd.

Onvervoegde werkwoordstammen worden aangetroffen als gebiedende wijs :

Toe as a $\mathrm{a}^{\mathrm{s}} \mathrm{o}$ !

$=$ Maak mij los!

$B a$ ōkōm, $b a$ adat è bahas

banòja!

$=$ Vestig godsdienst en adat in het land!

$A b e^{s}$ èlès saò taoengi!

$=$ Neem een zak!

en als onbepaalde wijs in het verband van een gebod of verbod:

Alé filang kōn anasaja! = Ga tellen de nangka-pitten!

Naè félé fòras satoedoe ${ }^{s}=$ Ga koopen een beetje rijst!

Nè toeto ${ }^{-s}$ mè ròsi $\mathrm{e}^{s}$ T. M.! = Ga het vragen daar aan T.M.!

Nè mòn $s i b \bar{o}$ manòs èdè! = Ga s.v.p. wegjagen die kippen!

Féré ndō tarén ${ }^{2}$ tès èrè! $=\mathrm{Ge}$ moet niet telkens weggaan van hier!

In de gebiedende wijs kan het stamwoord ook het persoonlijk voorvoegsel $2^{\mathrm{e}}$ persoon hebben:

Mitarén amè!

Mitoe'as $\mathrm{a}^{\mathrm{s}} \overline{0}$ !

$=$ Blijft gijlieden achter!

$=$ Laat gijlieden mij vrij!

Een stamwoordelijk werkwoord, dat onvervoegd geregeerd wordt door een eraan voorafgaand of meestal erop volgend 
persoonlijk voornaamwoord of ander onderwerp, schijnt wel steeds aan het Maleisch of Atjèhsch te zijn ontleend:

$\dot{\mathrm{E}}^{s}$ dès $\mathrm{o}$ èrè, doedōs $\mathrm{a}^{s} \overline{\mathrm{o}}$ sěnang

$\mathrm{sa}^{\mathrm{s} a} \mathrm{è}^{\mathrm{s}} \mathrm{baha} \mathrm{a}^{\mathrm{s}}$ banò èrè

$=\mathrm{Ik}$, ik woon ambteloos in dit land.

Nganga ba ò pisajò è $\mathrm{e}^{s}$ dè $=$ Zoo ge me niet vertrouwt. $N a i^{s}$ ja sa' a mè bachas kapaliah $=$ Hij klom het schip binnen. Toerōn ia sa'a òèngia mèria 'ōn $=$ De moesang daalde omlaag. Timboel ia dòsi banòn Malajoe $=$ Hij komt op daar in het Mal. land.

Hawél ia èlès nènè $\mathrm{Nja}^{s}$ Kandaja $=$ Hij huwde met Nja ${ }^{s}$ Kanda's grootmoeder.

Of het zijn woorden die wij geneigd zouden zijn als werkwoorden te beschouwen, maar waaraan de Simaloerees niet het begrip eener werking of verrichting hecht:

Běsang sa'a achinèja

Léng sa ${ }^{s} \mathrm{a}$ achinèja

Lèntos $\bar{o}^{s}$ dòsi, nitoetōs ès L. L. = Daar aangekomen, vroeg hij aan L. L.

Masarès ia nà falōngia èsambénè $=$ Alles raakte den reiger op zijn vleugels.

Ma- vormen.

Met het prefix ma- worden woorden gevormd, die soms als naamwoorden, soms als deelwoorden zijn te beschouwen:

a. van adjectieven :

ma-itō-itō

$=$ kleintjes, zachtjes.

ma-fél

ma-toeha

ma-résén

ma-ètěm, mètěm

b. van substantieven: (het afgeleide naamwoord beteekent "met ... wat het grondwoord aangeeft .)

ma-oetoes

ma-oemoer

ma-sala
$=$ groot.

$=$ oud.

$=$ goed, mooi.

$=$ zwart.

c. van woorden met verbale beteekenis:

$\begin{array}{ll}\text { ma-toeas } & =\text { afgeloopen. } \\ \text { ma-toetoes } & =\text { afgebrokkeld. } \\ \text { ma-toetōng } & =\text { aangestoken. } \\ \text { ma-ta'oe } & =\text { in rust. }\end{array}$


Deze $m a$-vormen schijnen wel gelijksoortig met de navolgende mal-afleidingen :

a. van adjectieven:

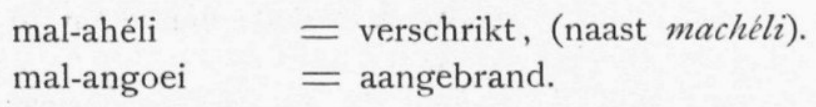

b. van substantieven:

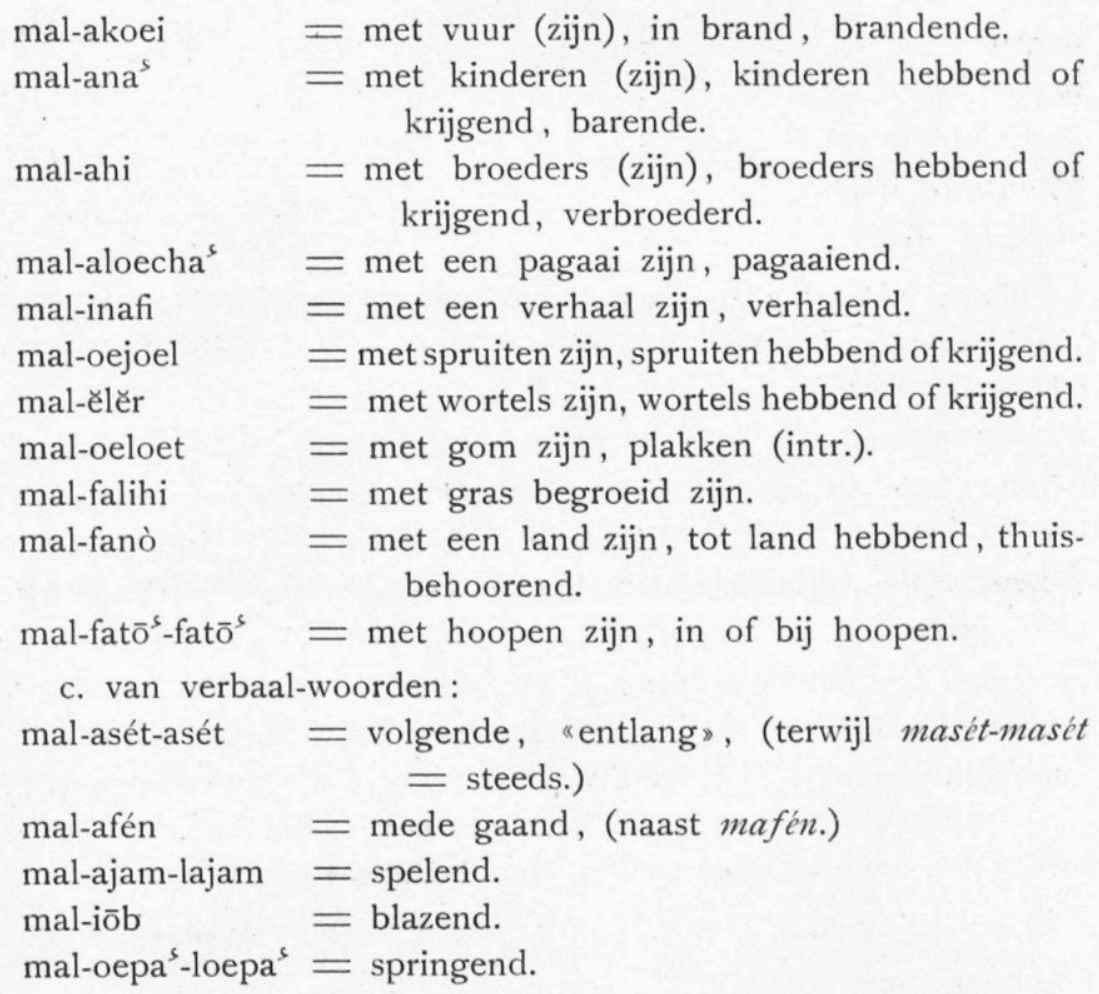

c. van verbaal-woorden :

mal-asét-asét = volgende, "entlang», (terwijl masét-masét $=$ steeds.)

mal-afén $\quad=$ mede gaand, (naast mafén.)

mal-ajam-lajam $=$ spelend.

mal-iōb = blazend.

mal-oepa ${ }^{\text {s-loepa }}{ }^{s}=$ springend.

In dit verband dienen ook genoemd:

$\begin{array}{ll}\text { mang-à̀ } & =\text { dorstig. } \\ \text { mang-oera } & =\text { jong. } \\ \text { mang-ida } & =\text { verlangend } \\ \text { mang-ila } & =\text { wetend. } \\ \text { mang-òlěng } & =\text { terug, huist } \\ \text { Verder: } & \\ \text { man-siloel } & =\text { spuwend. } \\ \text { man-tjòlan } & =\text { roeiend. } \\ \text { man-tai-tai } & =\text { poepend. } \\ \text { man-tètèhěm } & =\text { kuchend }\end{array}$


de uitdrukkingen:
man-sasachoeli
$=$ nu en dan.
man-sara-sira
$=$ ieder een.

en de deelwoorden, aangevende een wederkeerige handeling of een doen om het zeerst:
man-si-boeha
$=$ (iemand) opzoekend, elkaar ontmoe- tende zijn.
man-si-sntoe
man-si-jòjòs
man-si-ibò-ibò
man-si-tarén-tarén
man-si-toea-toea
$=$ elkaar slaande, vechtende zijn.
$=$ elkaar afrossende zijn.
$=$ elkaar verdrietende zijn.
$=$ elkaar verlatend.
$=$ doende wie het oudste is.

Het prefix $m a$ - wordt ook geplaatst voor transitieve verbalen.

Begint het verbaalwoord met $c h, h$, of $r$, dan krijgt het enkel ma- voor zich:
ma-chawal an
$=$ voedsel zoekende (zijn).
ma-hoekoer fò nòl
ma-rada ${ }^{5}$ ata
$=$ klappers raspende (zijn).
$=$ op de jacht (zijn) naar menschen.

Begint de verbaalstam met een klinker, dan wordt de $n g$ ingeschoven:

ma-ng-an lajap ma-ng-inòm òj ma-ng-antjan běti
$=$ rijst etende zijn.

$=$ waterdrinkende, het drinken van water.

$=$ een kist dragende of te dragen of het dragen van een kist.

ma-ng-èna ${ }^{s}$-ng-èna ${ }^{s}$ banò $=$ het land bekijkende.

Is de beginklank $s$ of $t$, dan komt daarvoor in de plaats de $n$ :

ma-nasai è̀nèn

ma-noengkoel

ma-nidaò ampōn

ma-noengkal

ma-nétés

ma-noeto $\bar{s}^{5}$

ma-narén
$=$ kleeren wasschende, van sasa.

$=$ wekkende,

$=$ vergeving vragende, „ tidaò.

$=$ kokende,

$=$ dragende,

$=$ vragende,

$=$ verlatende,
" soengkoel.

" toengkal.

» tétés.

» toetōs.

» tarén.

Voor beginletters $b, f, p$, treedt de $m$ in de plaats:

ma-majar

ma-moeha

ma-masal

ma-mati
$=$ betalende,

$=$ vindend, ontmoetend,, foeha

= wachtende (zijn),, $\mathrm{fa}^{\mathrm{s}} \mathrm{al}$.

$=$ rijst snijdende (zijn), » fati. 
ma-mòt

ma-mantjōng

ma-malènta

ma-malé-malé
$=$ stelende (zijn),

$=$ houwende, te houwen, » pantjōng.

$=$ besturende,

$=$ uitscheldende,
> fòt.

* palènta.

» falé.

Toch: ma-m-pòlèh $=$ cureerende zijn, dokteren, van pòlèh. Mogelijk omdat dit woord aan het Atjèhsch is ontleend? (Atj. poeléh $=$ hersteld, genezen.)

Zoo vindt men naast "mamajar» ook wel "mambajar».

\section{Oem-vormen.}

Er zijn ook deelwoorden, afgeleid van stamwoordelijke werkwoorden (en ma-vormen?), door invoeging van oem na de eerste medeklinker, c. q. na verdubbeling van de eerste lettergreep, of, als het woord begint met $m$ of een vocaal, door voorvoeging van oem-:

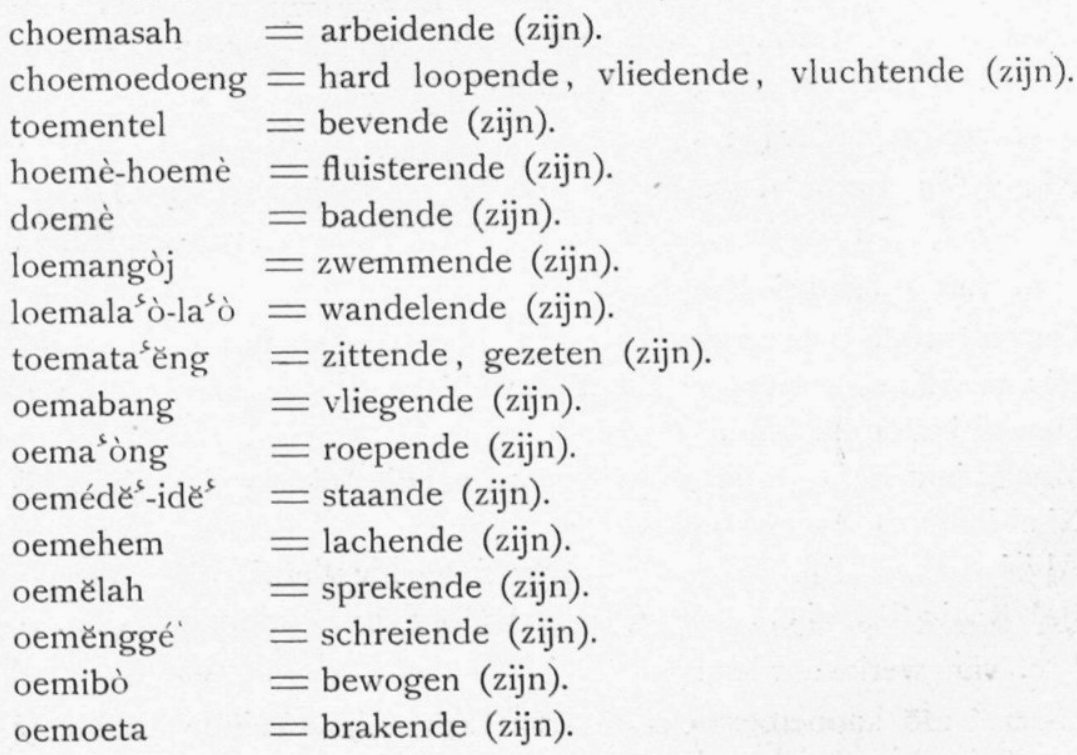

Die -oem-vormen schijnen dus wel den toestand van een persoonlijk of dierlijk onderwerp te beduiden, voor wat betreft deszelfs physieke of psychische verrichtingen, uitingen of gewoonten.

Toch - ik vond drie oem-vormen van een ander karakter: oemafas, vermoedelijk te verstaan als "niet zijnde», "mankeerend», van $f a^{s}=$ niet.

$\left.\begin{array}{l}\text { oemalòr } \\ \text { oemangòri }\end{array}\right\}=$ zijnde opdat, het is opdat, van òré $=$ opdat. 


\section{Voorbeelden :}

Ararōja singaoetòlòng 'ò? Oemafas balandjò? = Waarmee is het dat ik u kan helpen? Mankeert het aan geld?

Ba rasòb saò lěbangi banòng' $\bar{o}$, oemalòri masaél mamantjōng $\mathrm{e}^{s} \operatorname{de}^{s} \bar{o}=$ Laat hen graven een put als plaats voor mij, opdat het gemakkelijk zij mij te onthalzen.

Nga sènoe $\mathrm{e}^{\mathrm{s}} \mathrm{ba}^{\mathrm{s}}$ niba Si Kandang, miatoes mèria ès Sinafang, oemangòrija oekoerōng $=$ Als straks Si Kandang (de zaken) niet geeft, rapporteert gijlieden dan naar hier te Sinabang, opdat ik (hem) opsluite.

Doemasar $=$ nu, tegenwoordig, schijnt ook wel tot de hier bedoelde oem-vormen te behooren.

A-vormen.

Het prefix $a$-, c.q. gevolgd door $l$ of een nasaal, schept, al dan niet in verband met een suffix -an, vervoegbare werkwoorden van een causatief karakter:

a. van adjectieven:

Ni-a-désén matoesaj masihédia $=\mathrm{Hij}$ voltooide de moskee.

$\mathrm{Ni}$-a-désén sira radjò Aloeajania $=$ De radja van $\mathrm{A}$. verzoende hen.

b. van substantieven:

Oew-a-toefafa-n chabau

Ni-a-toefafa-n soerat

Oew-al-inafèn

Moe-al-inafèn

Ni-al-inafèn

Al-isi

$\mathrm{Ba}^{\text {s }} \overline{\mathrm{o}}$ ni-a $\mathrm{a}^{\mathrm{s}}$-oewi ...

c. van werkwoorden:

A-těrěs $a^{s} \bar{o}$ kapoetoesan silès $=$ Leer mij de eindwetenschap

Soeratia ni-a-bang-an angèn van het schermen.

$=\mathrm{Ik}$ zend een buffel.

$=\mathrm{Hij}$ zendt een brief.

$=\mathrm{Ik}$, gij, hij vertelt.

$=$ laden, vullen.

= Moge ik worden gelijk ...

$=$ Den brief heeft de wind doen vliegen, d. i. de brief is weggewaaid.

Ana $^{\text {s }}$ manò ni-a-bang-an majang $=$ Het kuiken, daarmee is de kiekendief weggevlogen.

Oew-a-choedoeng ia inan sioes $=$ Ik schaakte haar zoo juist.

Oew-a-ide ${ }^{s} \mathrm{a}^{s} \overline{\mathrm{o}} \mathrm{è}^{\mathrm{s}}$ dèta ${ }^{s}$ batoe $=\mathrm{Ik}$ ga staan op een steen.

Oew-a-tašng a’ō

$=\mathrm{Ik}$ zet mij, ik ga zitten. 
Ni-a-ta`ěng radjò darò $=$ Hij stelde aan twee vorsten. Ngamang rai'òh moe-a-la'ò, alé $=$ Mits ge u zelf kunt doen loopen d. i.: mits ge op uw eigen beenen kunt loopen, kom dan maar mee. Mè ni-a-lěkò teungkoeja ataja $=$ De teungkoe ging de lieden verzamelen.

Loema atajè moe-al-ilèi è $^{s}$ diò? $=$ Weet ge waar die man woont ? Ngang oew-al-ilèì! $=\mathrm{Ik}$ weet al waar!

(ilèi $=$ ila $\grave{e}^{s} \mathrm{i}=$ weten waar. Verg. het Atj. "toepat».)

$\mathrm{De}^{s} \overline{\mathrm{o}} \mathrm{fa}^{\mathrm{s}}$ ania oew-òl-òfil = Ik ken hem niet.

(òlòfil $=$ ila òfil $=$ weten hoeveel of hoegroot $=$ kennen. Verg. het Atj. "toesò $\mathbf{h}$.)

Ni-ang-ilil-ngilil oeloet anasaja $=$ Hij deed afdruipen de nangkagom.

Ta-a-mòlěng $\mathrm{e}^{s}$ isè banò èrè $=$ Geven we hem over dit land. Ta-an-soesoer mè rò̀ $\mathrm{i}$ è $\mathrm{S}$. = We geleiden elkaar naar $\mathrm{S}$. Ni-an-simèngělan $\dot{e}^{s}$ ata $=$ Hij maakte ruchtbaar aan het volk.

Van zulke causatieven laten zich door voorvoeging van mangdeelwoorden vormen :

Mangamòlěng

Mangadésén

Mangalěkò

Daifa $^{\text {s }}$ ia mangansala ana ${ }^{s}$ banò $=\mathrm{Hij}$ mag niet straffende zijn de landskinderen.

Daněng ami mangatoefafan-toe- $=$ Lang zijn we brieven zenfafan soerat

De vorm mamòlěng $=$ overgegeven, zou het vermoeden kunnen wekken, dat van de bovenbedoelde, causatieven ook $m a$ vormen bestaanbaar zijn:

Mamòlěng è diò banò èrè $=$ Overgegeven aan $u$ is dit land.

En daarop voortbouwend zou men er toe kunnen komen te twijfelen, of malěkò $=$ verzameld, marésén $=$ verzoend, enz. enz. mogelijk ook $m a$-vormen zijn van causatieven.

Om causatieven te vormen is het prefix a- niet steeds onontbeerlijk.

Soms gebeurt dat enkel met behulp van het suffix -an:

Oefaléwan batoeja

Moelèwan moeastasan

D1. 71 .
$=\mathrm{Ik}$ kantel den steen.

$=\mathrm{Ge}$ moogt (het land) afdrijven of droogleggen. 
Hier zij nog de aandacht gevestigd op de van causatieven afgeleide naamwoorden:

Oebah fachōng amajarannèh = Ik geef tabak in betaling.

Abé $^{s} \mathrm{ojj}^{s}$ anasajan ènènōh $=$ Haal water tot wassching van mijn goed.

Ancioean

$=\mathrm{Om}$ te doen stilliggen, rustplaats, halte, haven.

Tal van bijvoegelijke naamwoorden vertoonen het voorvoegsel $a$-:

\begin{tabular}{|c|c|}
\hline a-taré & $=$ lang, \\
\hline a-fite $e^{5}$ & $=$ kort \\
\hline a-tas & $=$ hoog \\
\hline a-těloe-těloe & $=$ laag \\
\hline a-raò & $=$ ver \\
\hline a-kĕn & $=$ nabij, \\
\hline a-fěl a-f̌̌l & $\begin{array}{l}=\text { met velen, talrijk, van fěl }= \\
\text { groot, }\end{array}$ \\
\hline a-fělas & $=$ breed \\
\hline a-lefò & $=$ groot \\
\hline a-facha ${ }^{5}$ & $=$ diep, van bacha ${ }^{5}=$ in, binnen, \\
\hline a-lafaj & $=$ vrouwelijk, \\
\hline a-fòrat & $=$ zwaar. \\
\hline
\end{tabular}

Zonder het prefix $a$ - ziet men die woorden veelal in verband met het bezittelijk voornaamwoord 3e pers. e.v. -nè :

Òfél taré-nè? = Hoe lang is het?

Òrònè raò-nè?

$=$ Hoe ver is het?

» tai-nè?

$=$ Hoe hoog is het?

Bennèjèh $=$ běl-nè-jè $\quad=$ Zoo veel of zoo groot als dat. Èna ${ }^{5}$ mòn lěfò-lěfò-nè chapaliah! = Kijk eens wat groote schepen!

Voor het accidenteel passief heeft men:

a. een $t a$-vorm:

Tapékéria sa ${ }^{5} a$ ò̀ngia

$=$ de moesang dacht, kwam op de gedachte.

Oewijè tarénè ata fa ${ }^{s}$ dōja ta-

běňm mang léw loean $=$ Zoo lange kerel gaat niet kopje onder, zoo overstekende de rivier.

Mèsa ba'̌rě tantarén

Oechaj tantarén è èrè

$=$ Niet een was er overgebleven.

$=\mathrm{Ik}$ wil niet achterblijven hier. 
Talfaléw alès batoeja

Talòjòl

b. een $m i$-vorm :
$=$ De steen was omgekeerd.

$=$ Uitgegleden.

Mièna $a^{s}-e_{n} a^{s} a^{s} \bar{o}$

$=\mathrm{Ik}$ kijk zoo wat rond.

Tè èrè $b a^{s}$ doe miram oelaò $\mathrm{S}$. = Van hier is het eiland $\mathrm{S}$. niet te zien.

Saò saò ratoe minaseun saò

ingkan lajap

Mibělah

$=$ Per vorst viel er op te brengen een bord rijst.

$=$ Gespleten.

c. een $a$-vorm misschien ? of hebben we enkel te doen met verleden tijds- of toestandsaanduidingen van anderen aard in:

Anan moefoesai fintoe? $\mathrm{Ba}^{\mathrm{s}} \mathrm{d} \overline{\mathrm{c}}$

nga oefoesai. Afoesai maoewi! = Waarom hebt ge de deur geopend? Ik heb ze niet geopend. $\mathrm{Ze}$ is van zelf opengegaan.

Chapalia ngang afoengkar = Het schip is al vertrokken.

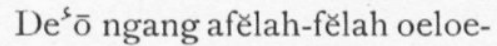
ngōh

$=$ Mijn hoofd is heelemaal stuk.

De optatief wordt uitgedrukt door $b a$ (= geve!), gevolgd door den persoons-exponent $3^{\mathrm{e}}$ p. $n i$ - of $\mathrm{ra}$-, soms als zoodanig, soms naar het mij voorkomt meer als nadrukswijzer:

Ba ni tantoe!

Ba ni mali!

$\mathrm{Ba}$ ra mèria!

Ba ni naoe!

Ba ni samò ratibtah!

Fa ja nitarén èsèrè!

Ba ni féréw masō's!

$\mathrm{Ba}^{5}$ o niïlas bòja!

$\mathrm{Ba}^{5} \bar{o}$ ni mataj, maè $\mathrm{ma}^{\mathrm{s}} \mathrm{o}=\mathrm{al}$ moet ik het besterven, ik ga toch.

$\mathrm{Ba}^{\mathrm{s}}$ ò ni mataj $\mathrm{è}^{s} \mathrm{ba}^{\mathrm{s}} \mathrm{ojj}^{\mathrm{s}} \mathrm{i} !=$ moge je sterven in het water! $\mathrm{Ba}^{5} \bar{o}$ ni a $a^{5}$ loewi tělan si ma-

toetoes èrè!

$=$ moge ik worden als deze afbrokkelende oeverwand!

Bovenstaand $b a$ wordt gemist in de volgende voorwaardelijke zelfvervloekingen, die een $b a^{5}$ bevatten, dat "niet» beteekent: 
$\mathrm{Ba}^{5} \bar{o}$ nihawan Ala ta ${ }^{5} a l a !=$ Niet mij vergezelle God! $\mathrm{Ba}^{s} \bar{o}$ nichawan kiramat nènèstah

Gěmò alès nènès ta è Oedjoeng! = Niet vergezelle mij de heiligheid van onzen voorvader "de dikke» en van onzen voorvader

$\mathrm{Ba}^{5}$ ana ${ }^{5} \bar{o}$ kakal bakal è dèta aan de Oedjong!

dōnia!

$=$ Mogen mijn kinderen niet bestendig zijn op deze wereld!

De $t i j d$, waarop of waarin de werking of verrichting plaats vindt, blijkt nimmer uit het werkwoord alleen, maar moet worden opgemaakt uit de zin. Soms wordt zij ook wel uitgedrukt met behulp van bijwoorden,

a. voor den verleden tijd: ngang, nga of $a$ :

Ngang nifachai fa'dōnè $\quad=$ Hij heeft zijn jas al aangetrokken.

Nga niabés aratònta = Hijheeftonzegoederengenomen.

Aratònèja masarè a niabés si-

mamòt

$=$ De dieven hebben al zijn goederen weggehaald.

Ngang òh chawél? Ngang! = Zijt ge reeds gehuwd? Reeds!

b. voor het tegenwoordige: bětěng of fëtëng, d. i. bezig met: Ia èdè achajmòh ja fětěng nian

chabaò

$=$ Ginds uw rijst, $z$ ij is bezig te worden opgegeten door de buffels.

Loemamò bettěng nitoetoeng $=\mathrm{Hij}$ is bezig uw huis in brand te steken.

Nga ${ }^{5} \mathrm{i}$ sara teungkoe, nga fě-

těng ia mangadji

$=$ Daar was een teungkoe die was bezig te mangadji.

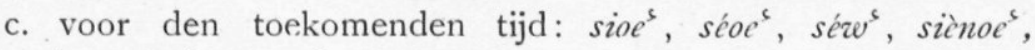
tjinoes, sìnoe, sinoe, dat als ons "straks», zoo in verleden als toekomst kan wijzen:

Loemanèja séoe ${ }^{s}$ nitoetoeng = Straks steekt hij zijn huisin brand! Sènoes nifoenoesò toeankoeèdè $=$ Straks zal die toeankoe je nog dooden.

Sènoe $e^{s}$ pantjōng mang $a^{s} \bar{o}$ ngang lěntōs dòfòngi

$=$ Straks onthals mij maar, als verstreken zijn twee nachten. 
Ook met behulp van het werkwoord màे of $m \dot{c}$, d. i. gaan, laat zich de toekomende tijd uitdrukken:

Rès $\bar{o}$ mè $\mathrm{a}^{\mathrm{s}} \overline{\mathrm{o}}$ mangadji $=\mathrm{Ik}$, ik ga mangadji.

Itaja-taja manti sènga mè prang?= Welke manti's trekken ten strijden?

¿'sisè èdè mèngia merrěs = Hij gaat slapen.

Tijdsbepalingen.

Dag

nacht

over dag

's nachts

middag

middernacht

's ochtends vroeg

" heel vroeg

tegen den middag

's namiddags

's avonds

nu

vandaag

gisteren

eergisteren

morgen

overmorgen

overovermorgen

vannacht, afgeloopen nacht komenden nacht een oogenblik

zooeven

straks

vroeger, eer

eertijds

begin, in den beginne

dán eerst

daarna
$=$ balal, falal.

$=$ bĕngi, fěngi.

$=$ falal fanòh.

$=$ fëngi fanòh.

$=$ techěl falal.

$=$ tenget bengi.

$=$ mèlafés.

$=$ mèlafés la òn. $^{s}$.

$=$ lepaj $^{s}$ ataj $^{s}$ balal.

$=$ atělós-tèló $\bar{o}^{s}$ falal, mata balal ngang atěloe-těloe.

$=$ ngang sandjōh.

$=$ (si)doema ${ }^{\mathrm{s}}$ ar.

$=$ bala(l) èrè.

$=$ sòri falal.

$=$ sòdibòngi, sidòfòngi.

$=$ děman, rěman.

$=$ döfòngi.

$=$ těloofěngi.

$=$ sòlafi.

$=$ sioe $^{s}$ běngéng.

$=$ sachadjab.

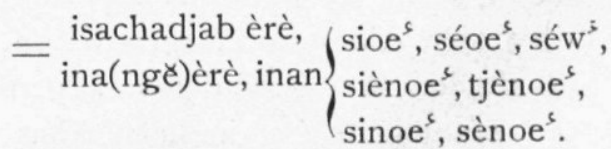

$=$ sioe $^{s}$, sènoe .

$=$ mòn, amòn, amònan, ina(ngè)èrè.

$=$ sèmònan.

$=$ oenèn-oenèn, amònan-mònan.

$=$ èněng masènoe.

$=$ sioe tèlè oeri, tèlèwi sioes 


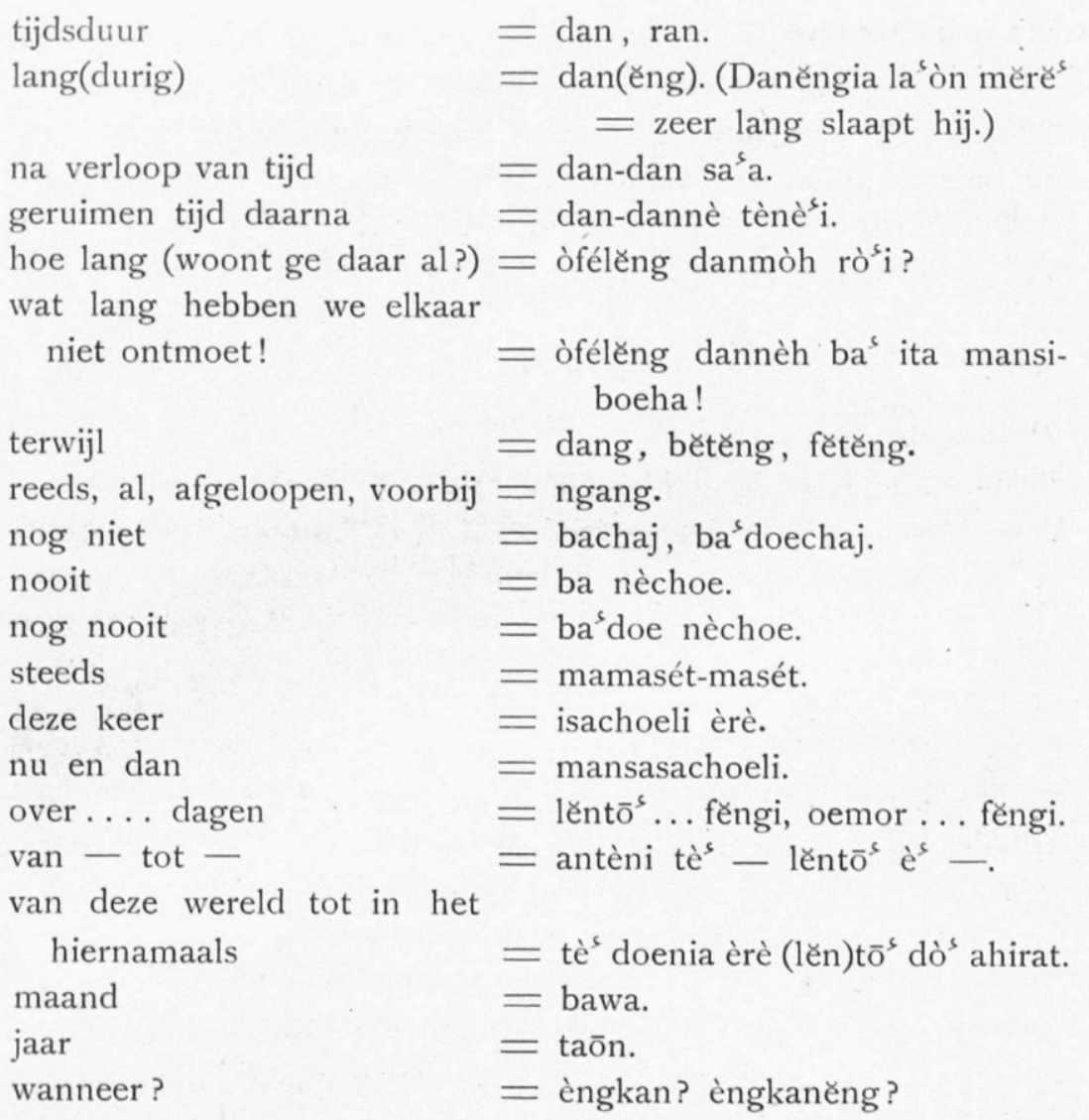

Aanwijz. en Betrekk. v.n.w.; Nadrukswijzers en Lidwoorden.

De aanwijzende voornaamwoorden zijn: $\grave{r} r \grave{e}, j \grave{c}$ en $\grave{c} d \grave{c}$.

Ėrè duidt op personen of zaken, die de spreker zich voorstelt tot hem, $1^{\text {en }}$ persoon, te staan in eenige betrekking, van tijd, plaats, bezit, of als voorwerp van zijn gesprek of zijn gedachte. (Verg. Dr. Snouck Hurgronje's Atjèhsche Taalstudiën.) Ḟ̀ en

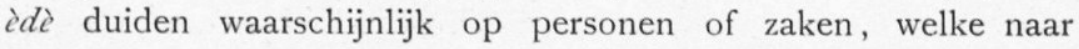
sprekers voorstelling in betrekking staan tot den toegesprokene (2en) of tot een $3 e n$ persoon, en zijn vaak met "die» en "gene» te vertalen; maar het verondersteld verschil wordt niet steeds in acht genomen:

$\grave{\mathrm{E}}^{s}$ dès ô èrè

Djami èsèrè

$=$ Wat mij betreft, ik.

Soempamas $i$ èrè

$=\mathrm{Wij}_{\mathrm{ij}}$ hier.

$=$ Deze onze eed. 
Ata roema'ar èrè

Diamèjèh

Béré angafan atajè
$=$ De menschen van tegenwoordig.

$=$ Gijlieden daar.

$=$ Verkoop die menschen (van u) niet!

Òmaè moeabés lajap fělnèjèh $?=$ Waarheen brengt ge rijst zooveel als dat? d. i. als ge daar bij u hebt.

Bènè $\left\{\begin{array}{l}\text { rèh } \\ \text { jèh }\end{array}\right.$

$\mathrm{E}^{5}$ isè èdè

Disira èdè

Zooveel als $\left\{\begin{array}{l}\text { dit. } \\ \text { dat. }\end{array}\right.$

Wachan wèrè, niachan wèdè $=\mathrm{Ik}$ zeg zus, hij zegt zoo. (Wèrè of oejèrè $=$ oewi èrè $=$ deze wijze. Wèdè of oejèdè $=$ oewi èdè $=$ gene wijze).

Oejèdè oejèrè raï

$=$ Het kan zus, het kan ook zoo.

$\dot{\mathrm{E}}^{s}$ èrè

$=$ Alhier.

Tès èrè, tè dia

Mèria (= mè-èrè-ia ?)

$=$ Van hier.

Dòs $i$, ròs $i, \grave{e}^{s} i s e ̀$

= Naar hier.

Tè dòs $\mathrm{i}$, tè isè

= Daar.

= Van daar.

Mè ròsi, mè isè

Ia èrè

$=$ Naar daar.

$=$ Deze of dit hier; alhier.

Ia ròsi, ia $a^{s}$ èdè

$=$ Die of dat daar; aldaar.

In diverse samenstellingen laten voornoemde aanwijzende voornaamwoorden zich vervangen door $i$, dat vermoedelijk als neutraal aanwijzend voornaamwoord moet worden opgevat:

Ia'sih

Bènèï

È'sh
$=$ Deze of dit hier, die of dat daar.

$=$ Zoo veel als dit, dat.

$=$ Hier, daar, er.

Loema atajè moealilèì è $\mathrm{e}^{\mathrm{s}}$ diò? $=$ Het huis van dien man, weet ge het «er» (daarvan) gij ? d. i. Weet ge waar die man woont?

Ngang walilèi $=$ Reeds ik weet het "er».

Zoo $i$ een woord voorafgaat, laat het zich beschouwen als nadrukswijzer of betrekkelijk voornaamwoord:

$\mathrm{Ia}^{\mathrm{s}} \overline{\mathrm{O}}$

Isachoeli èrè

Isachadjab èrè
$=\mathrm{I} k$.

$=$ Déze keer.

$=$ Dít oogenblik. 
Isaò fanòi

Kampōng isawi (i-saò-i)
$=$ Zeker land. (Mal. Jang saboeah negri.)

$=$ Die zekere kampong. (Mal. Kampong jang saboeah itoe.)

Meer zelfstandig bestaan als betrekkelijk voornaamwoord heeft $i$ in den vorm $s i$, met varianten $s j \grave{e}$ (= si jè? = jang itoe?), $s \grave{i}^{s}$ of $s \grave{e}, s j i, t j i^{s}$ enz. Isè, disè, risè $=h i j . \grave{E}^{s}$ isè, tè isè, mè isè, zie boven.

$I$ verrijkt met a geeft het als nadrukswijzer, lidwoord en persoonlijk voornaamwoord $3^{\mathrm{e}}$ persoon fungeerend $i a$ of $j a$, waarvan jang en djang:

Kakasnè ana ${ }^{s}$ tió $^{\mathrm{s}} i a$ sènga si-

laéja

$=$ de oudere van de muizenkinderen welke mánnelijk was.

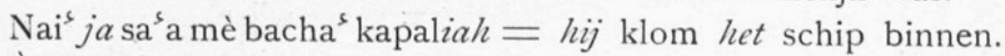

Èrèja djang damòlěng $\mathrm{è}^{\mathrm{s}} \mathrm{dès} \bar{o}$

* banò èrè

$=$ hoe $z i j$, ze gaven mij over dit land?

Dat ia vindt men ook als bestanddeel van de bijwoorden van plaats:

Ia èrè, djas èrè, jangě èrè,

Ia ròs $\mathrm{i}$,

Ia èdè, jangěsèdè, djangě èdè, djangèdè, jantaš̀̀dè, $J a^{s} i$, jangès ${ }^{s} i$, jantas $i$, djangěntas $i$.

Hebben we bij de substantieven inafi-nafi $=$ vertelling, inènawa $=$ ziel,, inihi $=$ droom, ina $=$ het voorbije, inafa $=$ rijstveld, inambünè $=$ bezitter, inahi $=$ jongere broer, te doen met een prefix in-, overeenkomend met het infix $-i n$ - in de woorden tinafa $=$ rijstveld, binor $=$ pap, sinoetoeng $=$ geroosterde spijs; of heeft men te doen met den nadrukswijzer $i$, gevolgd door een neusklank, als band met het volgende woord? Zoo «inahi» = ahi, in "Si $a^{s} a a^{s} \bar{o}$, inahi ${ }^{s}{ }_{\nu}=$ de oudere broer ben $\mathrm{ik}$, de jongere gij.

Telwoorden.

Men beweert verschillende telwoorden te bezigen naar den aard van de getelde zaken. Ook zouden vrouwen weer eene eigene telmethode hebben. Wel beschouwd zit het verschil echter meer in de voorvoegsels en aanhechtsels der telwoorden, welke i.h.a. zijn: voor menschen het pronominale prefix $3^{\text {e }}$ 
pers. m. v. $d a-$, voor dieren het achtervoegsel -siha, en voor zaken en vogels en visschen het dito - fò (d. i. "vrucht»). Vrouwen houden bovendien vast aan de telling òloe, siwa, oeloe voor $7,8,9$, waarvoor de mannen naar Maleisch voorbeeld salapan, sambilan, sapoeloe zeggen.

Vrouwen tellen: sara, doea, těloe, at, lima, ěněm, itoe, òloe, siwa, oeloe.

Menschen worden geteld: mèsa (hoewel *geen een ", niemand $=$ ba'sara of basdoe sara), darò, datěloe, dahat, dalima, daněm, daitoe, salapan, sambilan, sapoeloe.

Dieren: sara, roea, tělòsiha, akasiha, límasiha, něměngasiha, itoengasiha, enz.

Dingen en vogels: saò, doefò, těloefò, ataò, limafò, němafò, itoefò, salapan, sambilan, sapoeloe.

Verder ben ik tegengekomen:

\section{Sangaōn ifan}

Sachō ${ }^{-5}$ padan

Dō falal

Dòngawan èsnèn

Balaloe ara $\mathrm{fa}^{\mathrm{s}} \mathrm{ania}$
$=$ Een sirih-struik.

$=$ Eenplan,een verleidelijk voorstel.

$=$ Twee dagen.

$=$ Twee stukken goed.

$= \pm 10$ jonge klappers.

$=$ één keer (wenscht) gij (het), tien malen (wensch) ik (het).

$=7 \frac{1}{2}$ (mensch).

Daïtoe antafan

Oeba $^{s}$ isè radjònè dòsititilōng

banò èdè

$=\mathrm{ik}$ stel hem aan tot vorst van de helft van dat land.

Ook iha $=$ hoeveel, krijgt een voor- of achtervoegsel, verschillend naar den aard van het onderwerp: Ihaò loema $=$ Hoeveel huizen? Ihaò nasia $=$ Hoeveel visschen? Ihasicha kabaò $=$ Hoeveel karbouwen? Daïha sira atajè $=$ Hoeveel menschen?

Hoeveel

Veel

Velen

Weinig, weinigen

Een weinig

Meer

Minder

Nog minder
$=$ Iha, òfél.

$=$ àfell.

$=$ àfěl-àfèl.

$=$ échés. $^{\text {. }}$

= saché, satěpé.

$=$ oelangaj, ma $^{s}$ loelang, maïhaj.

$=$ asèb.

$=$ asèbaj. 


\section{Inafi-nafi ò̀ng alè balōng.}

Nga sara òèng èrè, nga ja è 'baha $^{s}$ i-saò fanò-i.

Ma-toeas-i sasa ès-bahas kampōng i-sawi sè-mòn-an rami těhěr ata ès-bahas kampōng i-sawi; djadi sas a těkědir oelahoe tasala ata ès-bahas kampōng i-sawi nga sira matòt ni-sabét karoeda; mèsa bas-ěrě tan-tarén, matòt sira ma-sarès. Ma-toeas-i sasa běsang-ia òèng inan-sinoes-ia ès-bahas kampōng i-sawi. Ara-ja $\mathrm{sa}^{s} \mathrm{a}$, ni-ènas manòs nga mal-fatōs ${ }^{s} \mathrm{fato}^{s}$. Ma-résén sa a lachan-nè òèng-ia, sěbab angang sès dai ni-an. Ara-ja sasa, ni-an sa ${ }^{s} a$ manòs-ia, òmaè-maè si ni-da lachan-nè, ara-ja alafaj ara-ja singèl, òmaè-maèng si ni-da. Ma-toeas-i sasa lamò-berrkalamòan ta-pékér-ia sa a ò̀ng-ia, sabab angang matòt manò ${ }^{s}$-ia, ba $\mathrm{ba}^{\mathrm{s}}$-eng-ĕrĕ sès daïs ni-an. Ni-anès sa'a sangaōn awas anasa sè-běl sè-ng-atas těhěr. Lěntōs ia sa'a ròs-i oejoel-nè, ni-ènas ibilang anawan. Ni-ènas sasa mè-ròs-i lòr, ni-ram sasa sara falōng, nga ja ròs-i $e^{s}$-dètas batoe; mangintaj-intaj anas -anas nas balōng-ia. Ta-pékér $\mathrm{sa}^{\mathrm{s}} \mathrm{a}$ lachan-nè òèng-ia, léng-nè : "Ia ròs-i makanan-ia atang.» 1 Ara-ja sasa, ni-toeroen-i sasa mè-ria-sōn, ni-paham-paham sasa òmaè tōs balōng-ia, ni-tòlòk-tòlòk mè $e^{s}$ i ralan-nè. Lěntōs ia sa ${ }^{s} a$ ria ès padang, ngang marō ja è $\grave{e}^{s}$-tōs-tōs balōng-ia. Ni-aòng-an sa`a, léng-nè: " $\breve{\mathrm{E}} \mathrm{ka}^{\mathrm{s}}$ balōng, moe-da sachō̄ padan ?» Léng balōng-ia léng-nè: "Ara-ja padan?» Léng òèng-ia léng-nè: "Naō oemabang tòlòk-tòlòk tès-ère tōs-nè, nga ròs-i sioe ${ }^{s}$ sangaōn anasa sè-nga-atas těhěr. Fasal-ěng $a^{s} \bar{o}$ ròs-i sioes. $\dot{E}^{s}$ dès $\bar{o}$-ja oe-nafoe tè-dia loemalasò. Mansiboecha ita ròs-i sinoes.» Léng balōng-ia léng-nè: "Raï $\mathrm{ma}^{s} \mathrm{a}$ ! Ni-naoe sasa oemabang balōng-ia mè-ròs -i sè-nga ni-ahan òèng-ia. Fěsang rò ${ }^{s}-i s^{s} a$, ni-naoe mantò $\mathrm{e}^{s}$ oejoel anasa-ja. $\dot{\mathrm{E}}^{s}$ ò̀ng-ia $\mathrm{sa}^{s} \mathrm{a}$, ni-naoe loemalas̀̀ tè-dia. Lěntō ia sas a ròs-i ò̀̀ng-ia ni-aòng-an sasa, léng-nè : " $\breve{\mathrm{E}} \mathrm{ka}^{s}$ balōng, ngang ò lěntō̌ dia?» Léng balōng-ia léng-nè: "Ngang!» Léng-nè sa'a òèng-ia léng-nè: "Alé dia-'ōn masa! Alé filang kōn anasa-ja! I-a ō mè-isè-dètas!» Mè ja ria-sōn sasa balōng-ia. Ni-anès sa'a 'oèng-ia anasa-ja. Ni-li sasa bò-nè saò sé-běl anasa-ja ngang mantjas, ni-chaōs sa'a anasa-ja, matòt chaloear sa a kōn-nè anasa-ja. Léng sasa oèng-ia léng-nè: "Filang-filang-ěng kōn-nè-ja!» Léng balōng-ia léng-nè: «Raï!» Matòt sasa ni-angilil-

1 De juiste beteekenis of waarde van dat woordje atang, dat wij meer zullen ontmoeten, heb ik niet kunnen ontdekken. 
ngilil oeloet anasa-ja mè-ria-sōon, ma-sarès -ia nà falōng-ia è ambés-nè, ma-sarè mal-oeloet sa'a ambés balōng-ia. Fěsang sa'a òèng-ia, léng-nè: " $\breve{\mathrm{E}} \mathrm{ka}^{\mathrm{s}}$ balōng, ò-fél-ěng kōn-nè-ja ma-sarès? * Léng balōng-ia léng-nè: "Féré měněng lě!» $\dot{\mathrm{E}}^{s}$ balōng-ia, fas"ěng daï ni-naō oemabang, ni-naoe ngang mal-oeloet ambés-nè-ja ni-naō oeloet anasa-ja. Ni-naoe sa ${ }^{s}$ a ma-loepak mè-ròs ${ }^{s}$, ma-loepak mè-ria. Ni-ram sasa òèng-ia tè-dò-i dètas oejoel anasa-ja, ba ${ }^{5}$-enng ia raï oemabang balōng-ia. Ni-toeroen-i sa'a òèng-ia mè-ria-sōn. Lěntōs ia ria-sōn òèng-ia léng-nè sasa: "Ò-fél-ěng sasa ètòngan-mò kōn anasa-ja?» Ara-ja sasa ni-akěn-an-ia òèng-ia mè-ròs-i élék balōng-ia, ni-radas ${ }^{s}$ chaě sasa falōng-ia. Léng sasa falōng-ia léng-nè: "Ara-ja sas a si moe-naō ès dès $\bar{o}$ èrè, fè ka òèng-gōh, moe-radas $a^{s} \overline{\text { ? }}$ 》 Léng sas a òng-ia léng-nè: "Araòria? 1 Oe-an s̀̀! I-a ${ }^{s} \bar{o}$ ma-lachal-lachal. Ran-ěng $\mathrm{a}^{s} \overline{\mathrm{o}}$ fa'-ěng mangan-mangan.» Léng sasa falōng-ia léng-nè: "Moe-an $\mathrm{a}^{5} \overline{\mathrm{o}} \mathrm{ma} \mathrm{a}^{5} \mathrm{a}$ ?" Léng òèng-ia léng-nè: "Ò-tang $\mathrm{ma}^{5} \mathrm{a}$ ?» 2 Léng balōng-ia léng-nè: 》Oewi èrè masa. Nga-ènga mangida $a^{s} \bar{o}$ moe-an, anè mènĕng mè $\grave{s}^{s}-$ rò $^{s}-i$ oejoel anasa-ja. Moe-èna ${ }^{s} \operatorname{sioe}^{s}$ mè-rò $^{s}-i e^{s}$ lòr. Nga rò ${ }^{s}-s^{s} s^{s}$ saò oelaò-oelaò. Ngang rò-i ami ma-sarès mal-fanò. Moe-da sioe $^{s}$ antěs, moe-an: moe-da nas, moe-an; òběn-òběn si moeda-nè.» Léng sasa ò̀̀ng-ia: "Atiě?» Léng balōng-nè-ja léng-nè: "Atiě!» Ni-toesaj sasa chaě falōng-ia. Ni-anè ${ }^{s}$ sa $^{s} a$ awa ${ }^{s}$ anasa-ja.

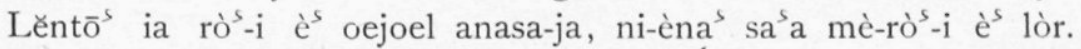
$\mathrm{Ni}$-ram sasa saò oelaò-oelaò, nga ròòo ${ }^{5} \dot{i}^{3}{ }^{3}$, è è $^{s}$-tědè lòr-ia. Nga sira ma-fatō ${ }^{s}$-fatō $\bar{s}^{s}$ rò $-i$ falōng-ia marō. Ma-toeas-i sasa toerōn ia $\mathrm{sa}^{5} \mathrm{a}$ òèng-ia mè-ria-ōn, léng-nè: "Atiě marō si moe-achan-ia, fè ${ }^{s} k^{s}$ balōng-sōh. Doemasar ara-ja masa dalan-ta mè-ròs-i è oelaò-oelaò-ja?» Léng sasa falōng-ia léng-nè: "Nè chawal-i masa filōs-ta.» Léng òèng-ia léng-nè: "Ara-ja?» Léng falōng-ia : "Roemasar nè ròs-i bachas kampōng, òmaè-maè ata sè-nga

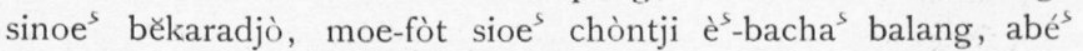
mè-ria. Oe-fasal-fa $a^{s}$ al ò è ${ }^{s}$-èrè. Néng chawal-i filo $\bar{s}^{s}$-ta-ja, òré ita ma-achè-ja ma-è mè-ròs ${ }^{s}$ ia». Ma-è ja sa a òèng-ia ma-chawal filōs-ia. Lěntōs ia $\mathrm{sa}^{\mathrm{s}} \mathrm{a}$ ròs $^{\mathrm{s}}$-i bahas kampōng-ia, nga sira fětěng běkarèdjò è ${ }^{s}$-bahas kampōng-ia marō. Fěngi fanò sasa ni-akěn-an

1 Denkelijk te verstaan als ara òré $i a=$ wat opdat het? = waartoe? Men vertaalde mị de uitdrukking in het Atjèhsch met peü̈ lòm? d. i. „wat verder?"

2 O.tang masa? werd in het Atjèhsch weergegeven met Peuë tjit?

$s$ Tot aanduiding van den grooten afstand wordt hier de $o$ in rò ${ }^{s} i$ lang aangehouden. 
ia mè-rò ${ }^{s}-i e^{s}$-bahas ata sè-nga běkarèdjò-ja. Mě-intaj-intaj, sira silab, ni-fòt sas a chòntji-ja, ni-abés $\mathrm{sa}^{5} \mathrm{a}$ choemoedoeng landjarlandjar sa'a mè-ròs -i ès-élés balōng-ia. Fěsang ia rò-i léng-nè: " $\breve{\mathrm{E}} \mathrm{ka}^{\mathrm{s}}$ balōng, ja-ng-ès-èrè filōs-ta-ja. Ma-è-ng-ita mè-ròs-i si moe-achan-ia.» Ra-naoe sa'a běkamè, ra-abés mè-ròs-i éténg asén sa a bilōos-da-ja. Ra-naoe sa a mès-bachas bilōs-ja. $\dot{E}^{s}$ balōng-ia, ni-kěmbang ambés -nè-ja, léng-nè : "Adésén-désén ita

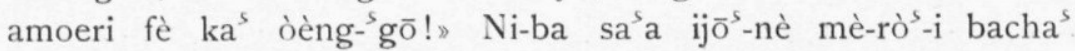
asén-ia. Soeda sa'a lěpas tè-nès alōn toedjoe tè-dia éténg angkal, léng sas a òèng-ia léng-nè: " $\check{\mathrm{E}} \mathrm{ka}^{\mathrm{s}}$ balōng, jang afasě-fasĕ aròf-ō.

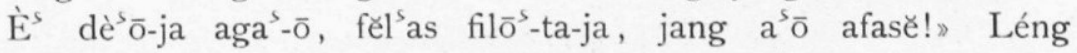
balōng-ia léng-nè: "Atiěr marō. Nga-wi masa, i-a ōo oe-pakar

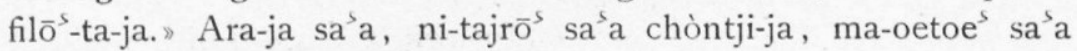
filōs-da-ja. Léng sa $\mathrm{sa}^{\mathrm{s}} \mathrm{a}$ falōng-ia léng-nè: "Ina-ngè-èrè fè $\mathrm{ka}^{\mathrm{s}}$ òèng-gō, mangida $a^{s} \bar{o}$ moe-an. Si-doema $a r e^{s}$ dès $\bar{o}$ èrè oemabang $a^{s} \bar{o}$; ès diò-ja tarén-ěng s̀̀ è'-bacha ${ }^{s}$ bilōs-ta-ja!»Ni-těnang sasa falōng-ia filōs-ia ta-bennem. Tan-tarén ia sa'a ès-bòfò òj ${ }^{s}$-ia òèng-ia, loemangòj mè-ròs-i, loemangòj mè-ria; fas-ěng ni-ilah ni-paham banò-ja. Fěsang sasa sara ijoe, ni-sèmbar-ia sa'a ijoe-ja òèng-ia. Balōng-ia sa'a ngang ia oemabang. Matòt sa'a inafi-nafi fès toean- ${ }^{-5}$.

Verhaal van den moesang en den reiger.

Er was een moesang, die woonde in zeker dorp. En in dat dorp was het vroeger zeer druk geweest van menschen in dat dorp; maar door Gods voorbeschikking waren de menschen in dat dorp tot den laatsten man toe weggehaald door den garoeda; niet één was er overgebleven, weg waren zij allemaal. Toen kwam de moesang van zooeven binnen dat dorp. Wat verder, hij zag dat er kippen waren in menigte. Verheugd was toen het hart van den moesang, omdat er was wat hij kon eten. Wat toen, hij at van de kippen, al naar zijn hart begeerde, of kippen of hanen, al naar hij zin had. En na verloop van tijd dacht de moesang na, want reeds op zijnde de kippen, was er niets wat hij kon eten. Hij klom in een nangka-boom die groot en heel hoog was. Gekomen tot in zijn top, keek hij links en rechts. Kijkende zeewaarts, werd hij gewaar een reiger, staande daar op een steen; loerende naar vischjes was de reiger. Des moesangs harte dacht na, en hij zeide: "Hij daar is het voedsel.» Wat toen, hij daalde naar omlaag, hij berekende waar 
omtrent de reiger zich bevond, en hij richtte daarheen zijn weg. Gekomen op het open terrein, stond hij dan ook tegenover den reiger. Hij riep, zeggende: "He broeder reiger, voelt ge voor een plannetje?» De reiger zei: "Wat voor plan?» De moesang zei: "Vlieg naar recht hier tegenover, daar is dan een nangka-boom die zeer hoog is. Wacht mij daar straks. Ik ga van hier loopen. We ontmoeten elkaar daar straks.» De reiger zei: "Goed!" De reiger vloog naar daar waar de moesang had gezegd. Daar gekomen, streek hij neer in den top van den nangka-boom. Wat aangaat den moesang, hij wandelde af van hier. Ginds aangekomen riep de moesang, zeggende: "He broeder reiger, ben je al hier?» De reiger zei: "Al!» De moesang zei: "Kom hier beneden! Kom de nangka-pitten tellen! Ik ga naar boven!» De reiger ging naar hier beneden. De moesang klom in den nangka-boom. Hij koos een groote nangkavrucht die al rijp was, hij klauwde de nangka, allemaal naar buiten kwamen de nangka-pitten. De moesang zei: «Tel de pitten!» De reiger zei: "Goed!» De gom van de nangka droop allemaal naar beneden, en alles kwam terecht op des reigers vleugels, en heelemaal met gom kwamen des reigers vleugels. Toen kwam de moesang, hij zei: "Zeg broeder reiger, hoeveel van die pitten zijn er totaal?» De reiger zei: «Doe even niet!» Wat aangaat den reiger, hij kon niet vliegen, doordat zijn vleugels plakten van de nangka-gom. Hij sprong der, en hij sprong her. De moesang zag boven uit den top van den nangka-boom, dat de reiger niet kon vliegen. De moesang kwam toen naar beneden. Beneden gekomen zei de moesang: "Hoeveel nangkapitten zijn er naar je telling?» De moesang naderde tot vlak bij den reiger, hij greep den reiger bij een poot. De reiger zei: "Wat doe je nu met mij, o broeder moesang mijn, pak je me beet?" De moesang zei: "Wel? ik eet je op! Ik heb honger. In lang heb ik niet gegeten.» De reiger zei: "Je eet me dus op?» De moesang zei: «Wat wou je dan?» De reiger zei : "Het is zoo gesteld. Wanneer je me wilt opeten, klim dan eerst naar daar in den top van dien nangka-boom. Zie dan zeewaarts. Daar ligt dan een eilandje. Daarop wonen wij allen bijeen. Wenscht ge straks eieren, ge eet ze; wenscht ge kiekens, ge eet ze; al naar ge wenscht. 》 De moesang zei: "Werkelijk?» De reiger zei : "Heusch!» Hij liet los de poot van den reiger. Hij klom in den nangka-boom. Gekomen in den top van den 
nangka-boom, keek hij naar daar in zee. Hij werd gewaar een eilandje, hèèl ver weg, midden in de zee. Daar waren ook massa's reigers. Daarop daalde de moesang naar omlaag, hij zei: "Het is toch waar wat je zegt, o broeder reiger. Hoe komen wij nu op dat eiland?» De reiger zei: "Ga zoeken dan onze boot.» De moesang zei: "Wat?» De reiger zei: "Ga nu ginds het dorp in, en waar er menschen aan het feestvieren zijn, steel daar de spon uit de pan, en breng die hier. Ik wacht je hier. Ga zoeken onze boot, opdat we fluks erheen gaan.» De moesang ging de boot zoeken. Toen hij kwam ginds in het dorp, was men daar ook bezig feest te vieren binnen het dorp. Nadat het donker was geworden naderde hij en begaf zich onder de feestvierende menschen. Hij loerde en loerde, en toen -zij er niet op letten, stal hij de spon, en liep daar mee weg snel naar ginds tot bij den reiger. Daar gekomen zei hij: "Wel broeder reiger, hier is onze boot. Laat ons nu gaan naar waar je zeide.» Ze maakten zich klaar, zij brachten naar het zeestrand hun boot. $\mathrm{Zij}$ gingen in de boot. Wat aangaat den reiger, hij spreidde zijn vleugels, zeggende: "Maken wij een roer o broeder moesang mijn!» Hij liet ook zijn staart in het water hangen. Nadat men was heengekomen door de zeven rollers vanaf het strand, zeide de moesang: "Zeg broeder reiger, mijn borst is nat. Ik denk, dat onze boot lek is, en ik daardoor nat ben!» De reiger zei: "Het is waar ook. Zijnde het aldus, zal ik breeuwen onze boot.» Wat toen, hij pikte weg de spon, en een gat was er in hun boot. Toen zeide de reiger: "Zoo even o broeder moesang mijn, wou je mij opeten. Nu vlieg ik weg; en jij blijft achter in onze boot!» De reiger trapte af zoodat de boot onder ging. Op het water bleef achter de moesang, zwemmende der, en zwemmende her; hij wist niet waar het land war. Toen kwam er een haai, en die haai hapte den moesang op. De reiger was al weggevlogen. Uit is de vertelling o mijn heer.

\section{Inafi-nafi anas $\mathrm{tio}^{\mathrm{s}}$.}

Nga saò inafi-nafi oewèrè fè toean-ōh, inafi-nafi ana tiōo chachan-nè. Nga roea tiōo èrè, nga sira bacha lantja ōtô ${ }^{5}$-dah. Ran-ran sa a mali ana $a^{5}$-da roea, sara silaé, sara silafaj. Ma-toeas-i sa a mataj ina-da $a^{5} a^{5}$ tiōo-ia. Ma-toeas-i sa'a ran-ran běsang 
$\mathrm{sa}^{\mathrm{s} a}$ kakas ${ }^{\mathrm{s}}$-nè ana $\mathrm{a}^{\mathrm{s}}$ tiō ${ }^{\mathrm{s}}$-ia, sè-nga silaé-ja, ni-achan è achi-nè-ja léng-nè: "Fè achi-ō, mè $a^{s} \bar{o} h$ malajam-lajam, mangènas ${ }^{s}$-ngènas banòh. Béré-(j)-ò tarén-tarén ${ }^{1}(\mathrm{t}) \mathrm{e}^{\mathrm{s}}-\mathrm{bacha}^{5} \overline{\mathrm{o}} \overline{\mathrm{o}}^{5}-\mathrm{ta}$ èrè. Mè $\mathrm{a}^{5} \overline{0}$ machawal-chawal an-ta(h) sakadjab mè-isè-tètaj. » Léng achi-nè-ja: "Raï fè oewòō.» Maè-ja(h) sa'a oewòō-nè-ja mès-tètaj, ni-asét-asét sasa éténg tamba ${ }^{5}$-iah, ni-ram sa a òj-ia è-bacha tambas-ia. Léng-nè sasa: "Ala haj! lawis baharoela èrè aflas těhĕr! Ara-ja sasa? ni-asét-asét éténg tamba ${ }^{5}$-ia, ni-ram sasa aji-nè tamba ${ }^{5}$-ia nga mè-bachas loewan aji-nè tamba ${ }^{5}$-ia. Tadè sa'a ni-ram alal chléng-chléng nga matòt běsèra ${ }^{5}-$ sèra $^{5}$ alal chléng-chléng-nja , ni-naoe ni-toetoe-toetoe òj-ia. Soeda-nè sasa léng-nè: "La! chapal èrè běl-nè-ja matòt běsèras'-sèras!» Ma-toeas-i sasa ngang běngi marōh, ni-ènas mata balal ngang a-těloe-těloe. Ni-naoe sasa mamòlěng mèrò $\mathrm{i}$ bacha ${ }^{5} \bar{o}^{\mathrm{t}} \overline{\mathrm{o}}^{\mathrm{s}}$-ia, ni-aòngan sa $\mathrm{s}^{\mathrm{s}}$ achi-nè-ja, léng-nè sasa: "Ala, fè adés $-\bar{o}$, $\mathrm{afla}^{5}$ těhěr alam doenia-jah!» Děmèn sas a falal fanòh, ni-achan sa $\mathrm{sa}^{5} \mathrm{è} \mathrm{achi-nè-ja,} \mathrm{léng-nè} \mathrm{:}$ "Maèh ndōh $a^{5} \bar{o} h$ balal èrè rè achi-ō, mangèna ${ }^{5}-n g e ̀ n a^{s}$ kapal sòri falal-iah. Béré-(j)-ò moe-tarén-tarén tès-èrè!» Léng achi-nè-ja: *Oe-chai ! Mali $a^{5} \overline{\text { oh }}$ rè oewòō malafén è diò fè wòō!» Ma-toeas-i $\mathrm{sa}^{5} \mathrm{a}$ achěsi sa $\mathrm{s}^{5} \mathrm{a}$ oewòō-nè-ja, léng-nè: "Béré-(j)-ò mali fala èrè. Sioe tèlè oeri oew-abés òh. Fala èrè féré-(j)-ò měněng mali malafén è dès ōh!» Ma-toeas-i sasa ni-anĕng-ia sasa achi-nè-ja. Ma-toeas-i sasa maè-ja oewòō-nè-ja mè-ròsi banò-nè sòri falal-ia, mangènas ngènas kapal-ia. Ran-ran sasa fëngi fanòh, mamòlěng ndō-jah

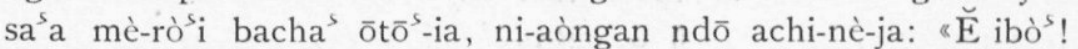
Ngang $a^{s} \bar{o}$ běsang tè-dò ${ }^{s} i$ mangèna ${ }^{s}$-ngèna ${ }^{s}$ kapal-ia, nga-alè ${ }^{s}$-alè ${ }^{s}$ sè-nga loechan-nè atang kapal-iah.» Léng achi-nè-ja: "Ara-ja loechan-nè chapal-ia, fè oewòō?» Léng sas a wòō-nè-ja: "Fai ${ }^{5} \mathrm{fa}^{5}$ oew-ilah isi-nè chapal-ia.» Léng sasa achi-nè-ja: "Ara-ja fè oewòō maè haj òh rĕman mangènas kapal-ia, fašeng?» Léng wòō-nè-ja: "Maè $a^{5}$ ōh fè achi-ōh rěman. Féré ndō tarén-tarén tès-èrè, naoe?» Léng sa $\mathrm{sa}^{\mathrm{s}} \mathrm{achi-nè} \mathrm{silafa-ja} \mathrm{léng-nè:} \mathrm{"Oe-chaj!}$ Mali $a^{5} \bar{h}$ i-sachoeli èrè malafén $e^{s}$ diòh, fè oewòō! Sòri falal léng-mòh: rai-fas měněng sò mali falal èrè; rěman w-abés òh sioe $^{s}$. Falal èrè oe-chaj tan-tarén è-èrè; mali $a^{s} \bar{h}$ mangèna chapal-i-jè.» Ma-toeas-i sasa ni-aněng-iah oewòō-nè-jah. Léng-nè sa a wòō-nè-ja: "Nga-mang rai òh moe-alasòh, aléh! Inama isè féré-(j)-òh sioe oeměnggé mè-isè dalan, ba $^{5}$ dai $^{5}$ oe-naoe sioe

Béréjò tarén-tarén of Béréw moe-tarén-tarén. 
manétés $e^{s}$ diòh, alès běngi sioe mamělěng ita mè-ria.» Léng sasa achi-nè-ja léng-nè: "Rai fas mang a $a^{s} \bar{o}$ moe-tétés! W-alas òh-la òh $a^{s} \bar{o}$ mawi. Sioe ${ }^{s}$ nga ita maè mè-rò $i$, mangènas chapal si moe-achan-iah, fè oewòō.» Léng sa'a oewòō-nè-ja: "Ras $\mathrm{i}$ masa, nga-mang rai moe-naoe, itaoe masah!» Ma-toeas-i sa a ra-naoe chaloear tè ${ }^{s}$-bachas ${ }^{s} \overline{t o}^{s}$ lantja-ja. Mè sira è-tètaj, ra-rò-nè alè $^{s}$ achi-nè-ja, ngang ni-afén-afén 'è-oeri wòō-nè-ja mè-rò'i è tètaj-iah. Ara-ja sa ${ }^{s} a$, lěntō sira è éténg tamba ${ }^{s}$-ia, léng sa ${ }^{s} a$ wòō-nè-ja: "Jantasi lawi baharoela ja! Nèchoe moe-ram?" Léng sasa achi-nè-ja léng-nè: "Atiěr marōh si moe-achan-ia fè oewòō!" Ma-toeas-i sasa ra-ětěj ra-asét-asét éténg tamba ${ }^{s}$-ia. Ran-ran ngang-ia ndōh araò-araò, wòō-nè-ja ni-aòngan ndōh achi-nè-ja, léng-nè: "Achè-achè-ja loemalasò-ja! Akěn-ěng ita mamòlěng mè-ròsi ita-jah!, Ra-ětěj sa'a loemala'ò-ja, malasét-lasét éténg tamba'-iah. Ran-ran sa'a lěntōs sira sas a mè-ròsi éténg loeaninjah. Léng-nè sa'a wòō-nè-ja : "Jantas-èdè chapal-iah si oew-achan

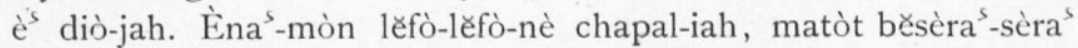
chapal-iah.» Ma-toeas-i sa ${ }^{5}$ a ra-tōrōn-i mè-ròsi éténg-éténg tělaniah, mè sira mangènas kapal-iah. Léng sa'a achi-nè-ja: *Fa dai ${ }^{\text {s }}$ oe-naoe è ${ }^{s}$ dès ōh fè oewòō. Naè mang è diòh mè-ròsi mè-bachas kapal-iah. Oe-fasal-fa $a^{s}$ al òh $e^{s}$-èrè, oe-èna $a^{s}$-èna ${ }^{s}$ òh tè ${ }^{s}$-èrèh. Inama féré(j)ò ran tè-isè fè oewòō. Sioe ${ }^{s}$ běngéng itah mamòlěng mè-rò $i$ ita-jah.» Léng sasa oewòō-nè-ja: "Rasi masah!» Maè-ja sasa wòō-nè-jah mè-bachas kapal-iah. Ni-foecha sa ${ }^{s} a$ sara chapal-ia nga masòròt-sòròt alè loechan-nè. Nai ${ }^{5}$-ja sa ${ }^{5}$ a mè $\grave{y}^{s}$-bacha kapaliah. Ni-ram sa'a ròsi bachas kapal-ia alès isi-nè chapal-ia. Ni-tōrōn-i sasa mè-bachas kapal-ia, ni-ènas mè-ròsi aròb, nioengkòn-iah manětěléō mè-ròsi bachas, ni-sědah sasa takès chěléng-injah. Machéli-ja sa a chěléng-iah, ni-lòngkòp sasa fa ba-nè chěléng-iah, fašeng-iah rai ${ }^{5}$ chaloear oeloe-nèh tè ${ }^{5}$-bachas chelléngiah. Ngang sa a oeméde $e^{s}-i d e^{s} i \bar{o}^{s}-n e ̀ h ~ m e^{s}-$ dèta $^{s}$, ngang ròsi bachas chěléng-iah oeloe-nèh. Bésang sasa achi-nè-ja, ni-aòngan sasa, léng-nè: « $\breve{\mathrm{E}}$ oewòō! alé sasa mamòlěng itah, fěnging!» Fa-dō ni-taě wòo-nè-ja. Ni-naoe fa: Ngang-ia mataj oewòō-nè-ja. Achinè-ja sasa ni-ětěj oemennggés, mangaòngan oewòō-nè-ja. Ara-ja $\mathrm{sa}^{\mathrm{s} a} \mathrm{a}$, ni-ènas ngang fěngi fanòh, ni-naoe sa ${ }^{5} \mathrm{a}$ mamòlěng achinè-ja, mèsa-mèsa chaj-ia. Ni-êtěj ni-asét-asét éténg tamba ${ }^{5}$-jah, mamòlěng-iah mè-ròs $i$ bacha ${ }^{s} \bar{o} \bar{t}^{s}$-iah. Ngang sa'a sapadoeò ralan mè-ròs $i$ raò-nè loemalas'ò-ja, ngang sandjōh, fěsang sa ${ }^{5} a$ sara majal ètěm. Satò ni-ram ana ${ }^{s}$ tiō $^{s}$-ia tè-dia loemalas ò-lasò, 
akěn sasa mè-ròsi élés majal-ia, ni-tangkĕm sasa ana tiōos-ia. Rò-nè $e^{s} i^{1}$ sa $^{5}$ inafi-nafi-ja fè toean-ōh.

\section{Verhaal van de jonge muisjes.}

Er is een verhaal als dit o mijn heer, 't verhaal van de jonge muisjes geheeten. Er waren twee muizen, die hun hol hadden in den grond. Na verloop van tijd kregen ze twee jongen, een mannetje, en een wijfje. Toen stierf de moeder van de jonge muisjes. En na een poos kwam de oudere van de jonge muisjes, dewelke was het mannetje, en hij zeide tegen zijn jongere zusje: «O zusje mijn, ik ga voor spel wat rondkijken in de wereld. Ga niet weg binnen uit dit ons hol. Ik ga even naar buiten om ons voedsel te zoeken.» Zijn zusje sprak: "Goed o broeder.» Haar broeder ging daarop naar buiten, hij volgde den kant van den vijver, en hij zag het water binnen dien vijver. Hij zeide: "Allah! deze oceaan is zeer groot!" Wat verder? hij volgde steeds den vijverkant, en hij zag dat het vijverwater ging naar de rivier. En hij ontwaarde mosselschelpen, die geheel verspreid lagen, meegevoerd door het water. Eindelijk sprak hij: "Allah! wat veel schepen liggen hier heelemaal verspreid!» Toen het avond was geworden, zag hij dat de zon al laag stond. Hij keerde huiswaarts naar ginds binnen het hol, hij riep zijn zusje, en zeide: «Allah, o zusje mijn, zeer groot is de wereld!» Den volgenden dag toen het licht was geworden, zeide hij tegen zijn zusje, zeggende: "Ik ga weer vandaag o zusje mijn, om te zien de schepen van gisteren. Je moet niet heengaan van hier!» Sprak zijn zusje: "Ik wil niet! Ik ga mee o broeder $U$ te volgen o broer!» Haar broer werd boos, en sprak: "Ga niet van daag. Later neem ik je mee. Vandaag moet je me liever niet volgen!» Daarop zweeg zijn zusje. Toen ging haar oudere broeder naar de plaats van den vorigen dag, om de schepen te bekijken. Na verloop van tijd toen de avond viel, keerde hij weer huiswaarts naar binnen het hol, en hij riep weer tot zijn zusje: "He liefje! ik ben gekomen van ginds waar ik heb gezien de schepen, en zij hebben lading die schepen.» Zijn zusje zei: "Wat is de lading van de schepen, broer?» Haar broer sprak: "Ik weet het niet wat de inhoud is dier schepen.» Zijn zusje sprak: "Broer, ga je morgen weer de

1 Rònèsi, een samentrekking van Rò-nè ès $i$, d. i. „het tot ervan is er." Dl. 71 . 
schepen zien, of niet?» Haar broer zei: "Ik ga o zusje morgen. Je moet hier niet van daan gaan, zal je?» Zijn zusje zei: "Dat wil ik niet! Deze keer ga ik mee U volgend, o broer! Gisteren zei je: ga vandaag liever niet; morgen neem ik je mee. Vandaag wil ik niet achterblijven hier; ik ga die schepen kijken.» Daarop zweeg haar broeder. Broer sprak: "Als je kunt loopen, vooruit! Maar je moet niet straks gaan huilen onder weg, ik kan je straks niet dragen, en het zal nacht zijn als we naar hier terug keeren.» Zijn zusje zeide: "Je hoeft me niet te dragen! Ik loop wel alleen. Straks gaan we daarheen, om die schepen te kijken waarover je spraakt, o broer.» Haar broer zeide: "Goed, als je kunt, gaan we dan!» Daarop gingen zij naar buiten binnenuit het aarden hol. $\mathrm{Zij}$ gingen naar buiten, met zijn beiden met het zusje, zij liep achter haar broer aan naar buiten. Toen, gekomen aan den vijveroever, sprak haar oudere broeder: "Hier is de groote zee! Zag je ooit zoo iets?» Zijn zusje zei: "Het is waar wat je verteld hebt o broer!» Daarop gingen ze voort volgende den vijveroever. Na verloop van tijd toen ze al ver waren gevorderd, riep de broer zijn jongere zusje, zeggende: "Vlug aanstappen! We moeten al weer gauw terug naar ginds!» $\mathrm{Ze}$ gingen voort met wandelen, volgende den vijveroever. Na eenigen tijd kwamen zij aan den rivieroever. Broer zeide: "Daar heb je de schepen waarover ik met je sprak. Kijk eens wat groote schepen, heelemaal verspreid die schepen.» Daarop daalden ze langs den oeverwand, om de schepen te gaan zien. Het zusje zei: "Ik kan dat niet doen broer. Ga jij maar het schip binnen. Ik wacht hier op je, ik zie je van hier. Maar maak het daar niet te lang o broer. Als het straks avond wordt moeten we terug naar huis.» Haar broer antwoordde: "Goed. Haar broer ging aan boord van het schip. Hij trof een schip dat heelemaal vol was met lading. Hij klom het schip binnen. Hij zag daar binnen het schip den inhoud van het schip. Hij daalde er in af, hij keek naar omlaag, hij bukte zich om naar binnen te kijken, hij raakte daarbij des mossels sluitspier aan. De mossel schrikte, hij sloot zijn mond, en muisjes hoofd kon er niet meer uit. Reeds stond overeind zijn staart naar boven, en daar binnen in den mossel bevond zich zijn hoofd. Kwam zijn zusje, ze riep, zeggende: "He broer! kom laten we naar huis gaan, 't wordt avond!». Haar broer antwoordde niet. Hij deed het niet: Hij was al dood haar broer. 
Zijn zusje zette het op een huilen, roepende om haar broer. Wat toen, ze zag dat het al donker was, en ze keerde huiswaarts het zusje, heel alleen nog maar. Zij volgde maar steeds den vijveroever, om terug te keeren naar binnen het hol. Reeds had zij den halven weg afgelegd, en de zon was al onder, toen kwam er een zwarte kat. Met dat zij zag het muisje van hier voortwandelen, al dicht bij en gaande naar daar vlak bij poes, toen pakte zij het muisje. Tot hier gaat het verhaal o mijn heer.

\section{Geschiedenis van Simoeloel.}

Sèmònan nga saò banò èrè, kahan banòja Simoeloel. Nga mèsa Toefa èrè, niabés kambéngnè, nifahajani alès boelawan, nitoesaj mè banòn Simoeloel. Lěntō dòsi, niabés Lafōng Lasali bahajan kambéngnèja. Matoeasi sa $a^{5}$ Toefaja mè nihawali bahajan kambéngnèja mè-ròs $\mathrm{i} \mathrm{è}^{s}$ Simoeloelia. Lěntōo dò ${ }^{s} \mathrm{i}$, nitoetoto ès Lafōng Lasalija: "Nga moeram kambéng'ōja ngalès bahajannè boelawan?" "Ngaja oefoeha $\grave{e ̀}^{s}$-èrè, ba dōmònia bahajan boelawan.» "Béré moeahan ba $a^{5} a m o ̀ n i a ~ b a h a j a n ~ k a m b e ́ n g s \bar{j}$ ! Mòlò nga bahajannè si oebai, malasénkan kambeng ${ }^{5} \bar{j}$ nga moeabé bahajannèi. Doemasari, nga $\mathrm{fa}^{\mathrm{s}}$ amòn moeamòlěng bahajan kambéng ${ }^{s} \overline{o j}$, oeprang s̀̀. Dai-naněng moeamòlěng marésén-désén, òré $\mathrm{fa}^{\mathrm{s}}$ ita mansiïbò-ibò.» $\mathrm{Ba}^{\mathrm{s}}$ dōmòn nitani Lafōng Lasalija. "Nga fa ${ }^{5}$ moetani masa si oeahani, dai fas ibò lahanmò, banòmò èrè oeprang." Matoeasi $\mathrm{sa}^{\mathrm{s}} \mathrm{a}$ niòlěng Toefaja mèria banònèja, nikarah ra $\mathrm{a}^{s}$ ajatnèja: "Doema ari ana $\mathrm{ra}^{5} a j a t^{5} \bar{j}$ masarè̀nè amè, doema ${ }^{s}$ ari mè ita $\grave{e ̀}^{s}$ banòn Simoeloel, mè ita prang alè Lafōng Lasali, sinaoe, nga niraboei ${ }^{s}$ bahajan kambéng itaja.» Matoeasi sa'a maè sira masarè ${ }^{s}$-sarè mè-rò ${ }^{s} i$ Simoeloelia. Lěntō ${ }^{s}$ dòs $\mathrm{i}$ daprang. $\grave{E}^{s}$-bahas daprang talō Lafōng Lasalija. Ninaoe hoemoedōng masarès-sarè $e^{s}$ tès - baha $^{s}$ banòja. Danaoe mè-ròsi hoemoedōng mè Aloeajan. Lěntōo dòsi, niahan Datô ${ }^{s}$ Pamoentja Aloeajan: "O-taén dō amè afěl-afěl ?» "Taén ami isè Simoeloel. Nga ami hoemoedoeng, daprang Toefa. Jéngia š̌babnèněng ami mèria masarès-sarès. $\mathrm{Ba}^{s} \mathrm{~s} n g$ dai maiènèngi. Ara sěbab dafoenoe ami Toefai? Sěbab nga ratoesaj mèria ba banòmasija kambéngda ngalè ${ }^{s}$ bahajan boelawan; léngda nga maiabés bahajan kambéngdai; ba dōmòn tadō nga maiabés! Jéngia sěbabnè ami daprangi. Doemasari, nganga moeda haj ami $\mathrm{è}^{\mathrm{s}}$-bahas banòi, anga rai, ami moetòlòng, haj ami safatoe èrè. $\mathrm{Nga} \mathrm{fa}^{5}$ ami moetòlòng, ba $\mathrm{a}^{5}$ nng ami safatoe èrè, dafoenoe 
Toefai.» "Ararōja singa oetòlòng s'ò? Oemafas balandjò? Moeatoe $\mathrm{e}^{s}$ dè $\bar{o}$, òré tantoe $\mathrm{e}^{s}$ dè $\grave{e}^{s} \bar{o}$ mamékéri.» Araja léng Lafōng Lasali è $e^{s}$ Pamoentja Aloeajania? "Tè èdoemòn ba balandjò, ba'ěng dai oelawan Toefaja. Nanga raï tidaònggōh, moetòlòng alè $\grave{e}^{s}$ diò sahoeli moetòlòng $\mathrm{a}^{s} \bar{o}$ alè $\mathrm{e}^{s} \mathrm{a}^{s}$ ra $\mathrm{a}^{s}$ ajatmò masarè sarè̀nè, nganga raï! Nganga $\mathrm{fa}^{5}$, ngang sa $\mathrm{s}^{5}$, niba ${ }^{5}$ Alah ta $\mathrm{N}^{5} \mathrm{ala}$ !» Matoeasi sa a léng Pamoentja ${ }^{5}$ Aloeajania: "Dai, basdoemòn mangapò; oetòlòng sò. Oemòr itoe fěngi lěntōo $a^{s} \bar{o}$ mè-isè $e^{s}$ banò Simoeloel. Doema ar nè mangòlěng mè-ròs $i$ diòja.» Nihais Lafōng Lasalija. Araja léngnè? "Oehai' mamòlěng mè-ròsi. Ara sěbab? Lěntō ${ }^{-5}$ dòsi, ngang sira ròsi Toefaja. Dang mamasal $e^{s}$ diò tè-dia, ngang maroe $a^{s} \bar{o}$ rafoenoe. Ara haj goenònè mè s̀ ròs $i$ manòlòng $e^{s}$ dè ōi ngang maroe $a^{s} \bar{o} b a^{s}$ enng? Aradōlia, nganga rai tidaòng ${ }^{s} \bar{o} h$, taänsoesoel mè-rò ${ }^{s} i e^{s}$ Simoeloeli.» Ara léngnè Pamoentjas Aloeajania? "Dai masa, pékéran nga è diò.» Ara léngnè Lasalija? "Nganga pékéran'ō èrè, oefas al mang ${ }^{s}$ ò." Daï masa. Nifa al itoe féngi. Lěntōo itoe fěngi, maè sira mè Simoeloelia masarès sarè $\grave{e}^{s}$ alè $\grave{s}^{s}$ radjò Aloeajania alè ra rajatnè sahoeli. Lěntōo dòsi è Simoeloel, daprang Toefaja. Matoeasi sa'a talō Toefaja. Matoeasi sasa, ngang sira talō, niadésén sira radjò Aloeajania. Ngang sira marésén, nitidaò radjò tè Aloeajania ès Lafōng Lasali : " $\grave{E}^{s}$ dè $\grave{s}^{s}$ èrè, Lafōng Lasali òj, mamòlěng $a^{s} \bar{o}$. Ara sěbab? Ngang amè maréén alè Toefaja. Aradōlia ata snggō nga mataj daitoeantafan. Balandjò dai fa $\mathrm{fa}^{\mathrm{s}} \mathrm{e}^{\mathrm{s}}$ dè $\mathrm{e}^{\mathrm{s}} \mathrm{m}$ mangètòng, karanò nga moeram bělnè si matòt doefò fanò mambalandjòi. Nga oewi masa, lěbi pékéran nga è diò Lafōng Lasali òj.» "Dai, basdoe mangapò Teukoe Ampōn òj! Oepékéri pahabaranmòi. $\grave{E}^{s}$-bahas $\mathrm{i}$ moefakat sira Lasalija: "Araòběněng si niahan radjòi? djangě-èdè ra ajatnèja daitoeantafan: singa mataj daitoe, singa sapés mèsa. Nga oewi $\mathrm{ma}^{\mathrm{s} a}$, nga $\mathrm{fa}^{\mathrm{s}}$ simban tapékéri, niba ita bèla atanèdè. Araòběněng dalannè, òré $\mathrm{fa}^{5}$ niba ita bèla atanèdè ? Běka haj ndō aratònè singa matòt è $\mathrm{e}^{s}$-baha ${ }^{5}$ prangtaja manòlòng $\grave{e}^{s}$ ita.» Matoeasi sa $\mathrm{s}^{\mathrm{s}} \mathrm{a}$, ara léngda Lasalija ? Malasénkan oewi èrè: "Dai fa ${ }^{s} \breve{n g}$ ia taba mamòlěng. Apabilò mamòlěng ia, mamajar ita aratònèdè. Dai-naněng, dai $\mathrm{fa}^{\mathrm{s}}$ ia taba mamòlěng. Lěbi marésén, $\mathrm{ba}^{5}$ ia mamòlěng, $\mathrm{ba}^{5}$ ita mamajar aratònèdè. Araja ralannè $b^{5}$ ita mamajar aratònèi alè $e^{s}$ atanè singa daitoeantafani? Araja dalannè $b^{5}$ ita mamajar?» Araja léng Lafōng Lasali? "Dalannè doel oré $\mathrm{fa}^{5}$ ita mamajar, taamòlěng $\mathrm{e}^{s}$ isè banò èrè. Ara sěbabněng tamolěng $\mathrm{e}^{\mathrm{s}}$ isè? Oré $b a^{s}$ 
ita mamajar aratonèdè, taba 'isè banòja, taba ia radjòsnta èrè̀. " Matoeasi $\mathrm{sa}^{5} \mathrm{a}$ maè sira mamoeha radjò Aloeajania: "Doemasari radjò òj, djami mèria mamoeha $e^{s}$ diò. Nga moeahan $e^{s}$ diama $i$, mamòlěng "ò mè-ròsi $e^{s}$ diòja. Doemasari tidaòmas $i e^{s}$ diò radjò òj: dai fasang s̀̀ mamòlěng! Mamòlěng dō-òně sò, oerimò daabés ndō banòmasija. Marésén-naněng moebasò ès-èrè.» "Ara labòngs ōh oebas ō è ${ }^{5}$-èrè banòmè ?» Ara léngnè Lafōng Lasalija ? "Labòmò oeba sò radjò èrè.» Ara léngnè radjò Aloeajania? "Dai-mòn samantarò nga haj $\mathrm{a}^{s} \overline{\mathrm{o}}$, dai $\mathrm{a}^{s} \overline{\mathrm{o}}$ radjònè- ${ }^{5}$ èrè; sinaoe $a^{s} \bar{o}$ malawan, nga akal s $\overline{0}$, samantarò $a^{s} \bar{o}$ òrif èrè. Ngang sènoe mataj $a^{s} \bar{o}$, bašng dai mè $\grave{~ a n a ~}^{s} \bar{o}$, sěbab kadang bašng moeba $\grave{\mathrm{e}}^{\mathrm{s}}$ ana'ōja radjòja.» Ara léngnè Lafōng Lasalija? "Nganga sènoe mataj s̀̀, mès ana'mò." $\mathrm{Ba}^{s}$ nitani radjò Aloeajania: "Ara sěbab bas oetani? Kadang bingòng sira, sědés s̀̀, moeabés tè ${ }^{s}$ isira.» Nitaě Lafōng Lasali: "Nganga bas ò pisajò è $e^{s}$ dès $\bar{o}$, maè ta běsoempah mè-rò tělan si matoetōj ${ }^{5}$ èdè, tala ${ }^{5}$ alan alè boelōng baroenggaj!» Matoeasi sa a maè sira mè-rò tělan si matoetoeisia, daäbés ung alè boelōng baroenggaja. Lěntōos dòsi, daide ${ }^{s}$ $\mathrm{è}^{s}$ iténg tělania singa matoetoesia. Daätas èng sira $\mathrm{e}^{5}$-aròb baroenggaja. Matoeasi sa a daäbé ${ }^{5}$ parasapan, datoetōng asò ${ }^{5}$, dabang basasannè soempadaja: "Diò Rifata, diò falal, singa mangatawi soempama $i$ èrè. Nga sènoe $e^{s}$ oeganggoe, oeabés namò èrè, ba ${ }^{5}$ $\bar{o}$ nia'sloewi tělan si matoetoes èrè! ba ${ }^{s}$ sapěrti $a^{s} \bar{o}$ boeloeng baroenggaj èrè mòlas $\mathrm{a}^{\mathrm{s}} \overline{\mathrm{o}}$ maoewi! mè lěngkōl bas doe malsoejoel, mès lěpoel basdoe mal'ělěr, ès-tědè nioetoes bělěng-bělěng, nga sènoe $^{s}$ oeabé $^{s}$ namòmòja oerinèi! Bersassi ta è Ala tasala! Jéngia soempantaï. Nga sènoe ${ }^{s}$ moekér tènè ${ }^{s}$ dè $^{s} \bar{o}$, bai ${ }^{s}$ atang sènoe $^{s}$ ana ${ }^{s} \bar{o}$, moembōng ${ }^{s} \bar{o}$, lěnto ${ }^{s}$ mè-rò ${ }^{s} i e^{s}$ soesoe-soesoe piōng ${ }^{s} \bar{o}, b^{s}$ dō sira malsoejoel mal ělěr, è ${ }^{s}$-tědè nioetoe ${ }^{s}$ bělěngbělěng!» Matoeasi sa'a daòlěng mès loema. Lěntōs sira ria $\grave{e}^{s}$ loema, danaoe kandoeri mès sagalò aulia dan anbia. Matoeasi $\mathrm{sa}^{\mathrm{s}} \mathrm{a}$, ara léngnè Lafōng Lasalija? «Doemasar radjò òj mamòlěng $\grave{\mathrm{e}}^{5}$ diò banò èrè; moelèwan, moeasta ${ }^{5} \mathrm{an}$, mamòlěng $\mathrm{e}^{s}$ diò , alès banò, alè $e^{s}$ ata, alè ${ }^{s}$ aratò masarèssarè. Saperrti $e^{s}$ dès $\bar{o}$ si(ng) $a^{s} \bar{o}$ mèsa èrè, mala énkan palèntaja $e^{s}-b a h a^{s}$ banò èrè nga $\mathrm{e}^{s}$ diò; $\grave{e}^{s}$ dè $\bar{o}$ èrè, doedo $\bar{o}^{s} a^{s} \bar{o}$ sĕnang $s a^{s} a e^{s}$-bahas banò èrè. » Ara léngnè radjòja? "Dai, mala énkan è diò doedōos sěnang s̀̀ è bahas banò èrè, bas dō salanè.» Matoeasi sasa, ngang mamòleng ès isè radjòja, matoeasi sasa nipékér-pékéri radjò Aloeajania: "Èrèja djang damòlěng ès dès $\bar{o}$ banò èrè? Ngang $a^{s} \bar{o}$ mandjadi 
radjò ès-bahas banò èrè. Ara-òběněng maramòsi kira-hiranè Toefa èdè? Malasénkan oebas isè radjònè dòsi tilōng banò èdè; oeba risè radjònè, òré rai samò maipěrami banò èrè. Kalau nga pěrkarò ès-bahas banò èrè, samò maihěman, saoepajò sěnang $\mathrm{a}^{5} \overline{\mathrm{o}}$, nga alèng ${ }^{5} \overline{\mathrm{o}}$ moefakat oekōman.» Matoeasi sa ${ }^{5} \mathrm{a}$ maè ja mansiboehan Toefaja. Lěntō $\bar{c}^{s}$ dòsi, léng Toefaja: "Òtaén sò Teukoe Ampōn òj?» "Taén $a^{s} \bar{o}$ isè banò. Maè $a^{s} \bar{o}$ mansiboehan $e^{s}$ diò. Doemas ari, malahi ta, tès doenia èrè (lenn)tōs dòs ahirat, malahi ta!» Ara léngnè? "Dai! Pòkòsnè nga ès diò. Sahoeli è diò, sapoeloengahoeli $\grave{e}^{s} d^{s} \bar{o}$. Oeda ita malahi!» Ara léngnè

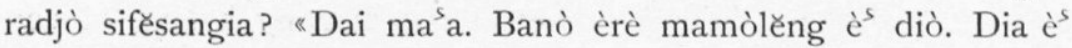
itilōng diò radjònè. $\mathrm{Si} \mathrm{a}^{5} \mathrm{a} \mathrm{a}^{5} \overline{\mathrm{o}}$, inahi ${ }^{s}$ ò. Sjéngia tanèkoe mèria mansiboeha alès diò, banò èrè samò tapalèntakan.» Matoeasi $\mathrm{sa}^{\mathrm{s}} \mathrm{a}$, dan-dannè tènè $\mathrm{i}$, běsang nènè $\mathrm{Dato}^{\mathrm{s}} \mathrm{Nja}^{\mathrm{s}}$ Noe. Ninaoe mangas dèsén kandang. Matoesaj kandangnèja, ninaoe maradas ata, nihandang. Afěl-afěl niloehan, niabés mès těpi. Lěntōs dòsi ès těpi, niangafan tiòs ${ }^{s}$-tiòs banò. Matòt ijè, niòlěng ndō mèria Simoeloel. Niras $\mathrm{da}^{s}$ ndō ataja, nihandang. Běsang bilōos tè-isès těpi, niangafan $\mathrm{e}^{s}$ isira. Matoeasi sasa oewi-oewi mangi masét-masét. $\dot{\mathrm{E}}^{\text {s }}$-bahas $\mathrm{i}$ běsang teungkoe mèsa tè-isès těpi. Daiha sira teungkoe èrè? Darò sira alès panglimanè Marahabit. Niahan teungkoeja è nènè $e^{s} D^{s} \bar{o}^{5} \mathrm{Nja}^{5}$ Noeja, ara léngnè? "Béré angafan atajè! Oe(w)isělamkan banò èrè. Léng sōlōtan Atjèh, léléq

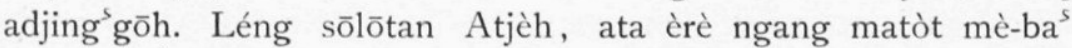
dòtan. $\dot{\mathrm{E}}^{\mathrm{s}}-\mathrm{baha^{s }}-\mathrm{i}$ mè nialěkō teungkoeja ataja tè $\mathrm{ba}^{\mathrm{s}}$ dòtan. Nifoeha, niabés mèria ba kampōng. Lěntōs dia, niba bas bilés ${ }^{s}$, nihoentji; mè haja mangalek $\bar{o}$ ataja. Oerinèja mè niabés nènè Datō $^{s} \mathrm{Nja}^{s}$ Noeja ata si-nga niba è-bas bilé $\mathrm{ia}$. Nitalan tòmba dòsi è ${ }^{s}-\bar{o} n$, niangkōlan tè-dia ataja mè-ròs matan tòmba ${ }^{s}$ ia, mataj masarèssarès. Matoeasi sasa běsangia teungkoeja, niahan ès nènès Datōs $\mathrm{Nja}^{\text {s }}$ Noeja: "Béré moefoenoe ata si-nga walěkōja! " $\mathrm{Ba}^{5} \mathrm{dō}$ nitani. Besang panglimanèja, danaoe bědasawa alès nènè Datō $^{s} \mathrm{Nja}^{s}$ Noeja; bědasawa, soeè ia Panglima Marahabitia. Danaoe bahampè alè nènè Datō ${ }^{5} \mathrm{Nja}^{5}$ Noeja. Asělò sira bahampè dia $\grave{e}^{s}$ angkal, danaoe bahampè mès $-\mathrm{ba}^{s}$ asén. Dapè nisilò bō nè è ${ }^{s}$ batoe nènè Datō ${ }^{s} \mathrm{Nja}^{s}$ Noeja, ba ěng dai ia nifěngkès. Matoeasi $\mathrm{sa}^{\mathrm{s} a}$ Panglima Marahabitia niòleng mèria angkal. Tantarén ia dòsi è-ba ${ }^{s}$ òwé $^{s} i a$. Lěntō ${ }^{s}$ těloe fěngi mè nièna ${ }^{5}$, nga haja, bas dō ja nga mataj, talfaléw alè batoeja. Matoeasi sa ${ }^{5}$ manidaò ja ampōn è ${ }^{s}$ Panglima Marahabitia. Léng pangli- 
maja: "Nga moetani si wahan èrè, oetoesas ò. Nga sisè ba"

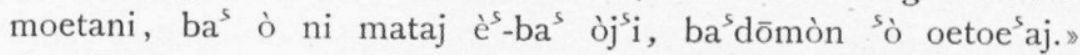
Ara léngnè nènè Datōs $\mathrm{Nja}^{s}$ Noeja? "Nga-mang $\mathrm{a}^{\mathrm{s}} \overline{\mathrm{o}}$ moetoes aj, ba'dōmòněng oefoenoe ataja. Jéngia panglima òj tidaònnggō sabōli-bōli è $e^{s}$ diò: toesas $a^{s} \bar{o}$ !» Nitoesaj. Niòlěng mèria angkal,

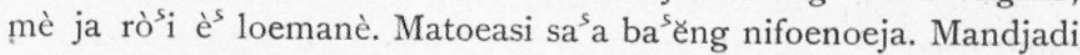
nisělamkan banòja è isè teungkoeja. Ngang mandjadi nisělamkan banòja, niòlěng mès Atjèh teungkoeja. Lěntōs dòsi ès Atjèh, nifoeha soelōtan Atjèh. Ara léngnè ès soelōtania? "Banò si moeahan è dès ōja si-nga maè oeisělamkania. Jéngia si-nga watoe ${ }^{s}$ $\grave{e}^{5}$ diò soelōtan Atjèh òj.» Ara léngnè soelōtan Atjèja? "Dai, $\mathrm{ba}^{\mathrm{s}}$ mangapò. Aradōlia naè òlěng. Dja èrè saò toenggas. Abés mè-ròs $\mathrm{i} \mathrm{è}^{s} \mathrm{Lo}^{s}$ Simoeloel. Lěntōo dò $\mathrm{i} \mathrm{a}^{s}$ désén masihéd. Ngang sènoe $^{s}$ matoesaj moeas désén, ba ōkōm, ba adat è ${ }^{s}$-bahas banòja. » Matoeasi sasa maè ja mèria $\mathrm{è}^{s} \mathrm{Lo}^{s}$ Simoeloelia. Lĕntōo dia nias désén matoe ${ }^{5}$ j masihédia. Ngang matoe aj masihédia, niba imeum, niba hatéb, niba filal, pangoeloe moekén. Ngang si-nga mamalènta hoekōm, niatašeng radiò. Niatašng radjò darò, malintang darò, datōos dagang mèsa.

\section{Geschiedenis van Simoeloel.}

In vroeger tijd was er een land, de naam van het land was Simoeloel. Er was een Toefanees, hij nam zijn bok, hij tuigde dien op met goud, hij liet hem los in het land Simoeloel. Gekomen tot daar, nam Lafōng Lasali het bokkentuig. Toen dat geschied was ging de Toefanees zoeken het bokkentuig naar daar in Simoeloel. Gekomen tot daar, vroeg hij aan Lafōng Lasali: "Hebt ge gezien mijn bok met zijn tuig van goud?» "Ik heb hem aangetroffen alhier, niet echter met tuig van goud.» "Ge moet niet zeggen dat zonder tuig was mijn bok! Wel degelijk was er zijn tuig dat ik hem aandeed, maar mijn bok hebt gij ontnomen zijn tuig. $\mathrm{Nu}$, gesteld niet ge geeft terug het tuig van mijn bok, dan beoorlog ik je. Het ware beter ge gaaft het terug goedschiks, opdat niet wij elkaar verdrieten.» Niet echter luisterde Lafōng Lasali. "Is het dat niet ge luistert naar wat ik zeg, laat dan niet droef zijn uw hart, als ik dit uw land beoorlog.» Daarop keerde huiswaarts de Toefanees naar hier in zijn land, hij riep bijeen zijn onderdanen: "Thans mijn onderdanen te gader gij, nu gaan wij naar het land Simoeloel, wij gaan oorlogen tegen Lafōng 
Lasali, wat 't doet, hij heeft geroofd het tuig van onzen bok. » Daarop trokken zij tezamen naar Simoeloel. Gekomen aldaar oorloogden zij. Onderwijl zij oorloogden verloor Lafōng Lasali. Men vluchtte gezamenlijk uit het land. $\mathrm{Zij}$ deden daarheen vluchten naar Aloeajan. Aangekomen tot daar, zeide Datoes Pamoentjas Aloeajan: "Van waar komt gij met zoo velen?». "Wij komen van Simoeloel. Wij zijn vluchtende, beoorloogd door de Toefaneezen. Dat is de reden er van dat wij herwaarts kwamen tezamen. We konden het niet houden. Wat is de reden dat z.ij ons dooden de Toefaneezen? Omdat zij loslieten naar hier in ons land hun bok met gouden tuig; zij zeggen dat wij hebben genomen het tuig van hun bok; wij hebben het echter niet genomen! Dat is de reden ervan dat zij ons beoorlogen. $\mathrm{Nu}$, zoo ge wilt dat we leven blijven in het land, als het $U$ belieft, helpt $U$ ons dan, terwijl wij allen er nog zijn. Zoo ge ons niet helpt, dan is het met ons allen gedaan, gedood worden we dan door de Toefaneezen.» "Waarmee is het dat ik $U$ dan zou helpen? Mankeert het aan geld? Zegt gij het mij, opdat ik het met zekerheid overdenke.» Wat zeide Lafōng Lasali tot Pamoentja" Aloeajan? "Het is niet dat ik geen geld heb, waarom ik niet kan weerstaan den Toefanees. Als in te willigen is mijn verzoek, helpt $U$ mij dan tegelijk met Uzelf en Uw onderdanen met zijn allen, als het mocht! Kan dat niet, dan is het uit, en Gode overgelaten !» Daarop zeide Pamoentja" Aloeajan: "Goed, 't is niets; ik zal U helpen. Over zeven nachten kom ik ginds in het land Simoeloel. Keer nu derwaarts terug gij.» Lafōng Lasali wilde niet. Wat zeide hij ? "Ik wil niet terugkeeren daar naar toe. Waarom? Kom ik daar, dan zijn daar reeds de Toefaneezen. Wachtend erop dat gij van hier komt, zal ik toch reeds door hen gedood zijn. Wat nut het dan nog zoo ge derwaarts gaat om mij te helpen wanneer ik toch al niet meer zal wezen? Wat dan slechts, wanneer mocht worden ingewilligd mijn verzoek, gaan we dan tezamen naar Simoeloel.» Wat zeide Pamoentjas Aloeajan? «Goed dan, zooals U wilt.» Wat zeide Lasali? "Mij dunkt, ik wacht dan maar op U.» Goed dan. Hij wachtte zeven nachten. Gekomen tot zeven nachten, gingen zij naar Simoeloel allen tezamen, met radjo Aloeajan en diens onderdanen tegelijk. Gekomen te Simoeloel, beoorloogden zij de Toefaneezen. Aan het eind verloren de Toefaneezen. Vervolgens, nadat ze het 
hadden verloren, verzoende hen de radjo van Aloeajan. Nadat ze verzoend waren, vroeg de vorst uit Aloeajan aan Lafōng Lasali: "Wat mij aangaat, o Lafōng Lasali, ik keer huiswaarts. Waarom? Gijlieden zijt al verzoend met de Toefaneezen. Maar van mijn menschen zijn er $7 \frac{1}{2}$ gesneuveld. De uitgaven is het mij niet mogelijk te berekenen, want ge hebt gezien hoeveel er is opgegaan wegens het doen van uitgaven voor twee landen. Zijnde het aldus, zoo staat het aan $\mathrm{U}$ terzake te oordeelen o Lafōng Lasali.» "Goed, 't is niets Teukoe Ampōn! Ik zal overdenken uw zeggen.» Onderwijl overlegden de Lasaliërs: "Hoe was het dat de vorst zeide? daar waren van zijn onderdanen $7 \frac{1}{2}$ man: 7 gesneuvelden, en één verwonde. Zijnde het aldus, (zou) wanneer wij het niet goed overleggen, hij ons de bloedschuld opleggen voor die zijn lieden. Hoedanig is de uitweg, opdat hij ons niet oplegge de bloedschuld voor die zijn lieden? Daarenboven ook nog de kwestie van zijn kapitaal dat is opgegegaan in onzen oorlog om ons te helpen.» Vervolgens, wat zeiden de Lasaliers? Dat was aldus: "Wij moeten hem niet huiswaarts laten gaan. Wanneer hij huiswaarts keert, hebbẹen wij dat zijn kapitaal te betalen. Het is beter, dat we hem niet laten teruggaan. Het is beter, dat hij niet huiswaarts keert, en wij niet betalen zijn kapitaal. Wat is de weg daartoe dat wij niet vergoeden zijn kapitaal en zijn menschen welke $7 \frac{1}{2}$ zijn? Welke is de weg dat we niet betalen ?» Wat zeide Lafōng Lasali? "De weg slechts opdat wij niet hebben te betalen, (is dat) we overgeven aan hem dit land. Waarom geven wij het hem over? Opdat niet wij betalen dat zijn kapitaal, geven wij hem het land, maken wij hem onzen vorst hier!» Daarop gingen zij opzoeken den radjo van Aloeajan: "Thans o radjo, zijn wij herwaarts gekomen om $U$ te ontmoeten. Ge hebt gezegd tot ons, dat ge wildet huiswaarts keeren. $\mathrm{Nu}$ is ons verzoek aan $\mathrm{U}$ o vorst: ge moest niet terugkeeren! Keert ge toch terug, dan nemen zij achter uw rug weer ons land. Het ware beter dat ge $U$ hier vestigdet.» "Wat zou mijn voordeel zijn zoo ik mij vestigde hier in Uw land?» Wat zeide daarop Lafōng Lasali? " $\mathrm{Uw}$ winst ware dat $\mathrm{ik} \mathrm{u}$ vorst maakte hier.» Wat zeide Radjo Aloeajan? "Dat gaat goed zoolang ik er nog ben, dan kan ik vorst zijn alhier; want ik sta mijn man, ik heb mijn verstand, zoolang ik leef. Maar ben ik straks gestorven, dan gaat het niet over aan mijn kinderen, omdat ge misschien mijn 
kinderen niet toestaat vorst te worden.» Wat zeide Lafōng Lasali? «Wanneer later gij zult zijn gestorven, gaat het over aan uw kinderen.» Hij vertrouwde het niet de radjo van Aloeajan: "Waarom stel ik er geen vertrouwen in? Misschien zijn zij dom, en gij geslepen, dan neemt ge het van hen.» Lafōng Lasali antwoordde: "Wanneer ge mij niet vertrouwt, laat ons dan gaan zweren aan gindschen afbrokkelenden rivieroever, dat we mogen verwelken als de blaren van den moerōng-boom! Daarop gingen zij naar den afgebrokkelden rivieroever, en namen zij blaren van den moerōng-boom. Daar gekomen, gingen zij staan aan den rand van den afgebrokkelden oever. $Z$ ij gingen zitten onder den moerōng-boom. Daarop namen zij een vuurtest, zij brandden benzoë, zij uitten de bewoordingen van hpn eed: "Gij God, Gij Zon, die kent dezen onzen eed. Ware het ik straks verstoorde, ik nam deze waardigheid, moge het mij dan vergaan als dezen afgebrokkelden oeverwand! mogen mijn blaren vallen als de blaren van dezen moerōng! naar den top krijge ik geen spruiten, naar de aarde geen wortels, in het midden worde ik doorboord door torren, wanneer ik later mocht nemen Uw waardigheid! Tot getuigen nemen wij Allah! Dat is onze eed. Als ik er van mocht afwijken, of - men weet het niet - mijn kinderen zouden dat doen, mijn kleinkinderen, tot mijn achter-achterkleinkinderen toe, mogen zij dan niet uitspruiten of wortelschieten, en in het midden door torren worden doorboord!» Daarop keerden zij huiswaarts. Hier tehuis gekomen, richtten zij een feestmaal aan voor heiligen en menschenkinderen. Toen dat was afgeloopen, wat zeide toen Lafōng Lasali? "Thans o vorst gaat aan u over dit land; ge kunt het afdrijven, ge kunt het vastleggen, het gaat over aan $u$, en land, en bevolking, en bezittingen tegader. Wat speciaal mij aangaat, - het bestuur binnen dit land berust bij $\mathrm{u}$; ik, ik woon vrij binnen dit land.» Wat zeide daarop de radja? "Goed, zoo gij vrij wilt wonen in dit land, daar steekt geen kwaad in.» Daarop, nadat het vorst zijn op hem was overgegaan, overpeinsde Radjo Aloeajan: "Hoe is het dat zij geven mij dit land? Ik ben vorst geworden in dit land. Hoedanig zal ik nu gunstig stemmen de gedachten van dien Toefanees? Ik zal hem maken radjo van de helft daar van het land; hem stel ik daarover aan tot vorst, opdat we samen tot welvaart brengen dit land. Zoo er zaken zijn binnen dit land, dan berechten wij 
ze samen, opdat het aangenaam zij voor mij, zijnde er mijn gezel om mee te beraadslagen over de berechting.» Daarop ging hij opzoeken den Toefanees. Gekomen aldaar, sprak de Toefanees: "Vanwaar komt ge o Teukoe Ampōn?» "Ik kom van de kampong. Ik ging $\mathrm{u}$ opzoeken. Thans, laat ons broeders zijn, van af deze wereld tot in het hiernamaals, laat ons broeders zijn!» Wat zeide hij daarop? «Goed! Dat hangt van $\mathrm{u}$ af. Een keer is het de wensch van u, tien malen (is het de wensch) van mij. Ik wil graag dat wij broederschap sluiten!» Wat zeide daarop de vorst die was gekomen? "Goed dan. Dit land keert terug aan u. Hier van deze helft zijt gij de vorst. De oudere broer ben $i k$, de jongere gij. Dat is het waarvoor $\mathrm{ik}$ hierheen ben gekomen om $\mathrm{u}$ te ontmoeten, opdat wij dit land tezamen zouden besturen.» Toen dat was afgeloopen, geruimen tijd nadien, kwam de grootvader van Datoe ${ }^{5} \mathrm{Nja}^{5}$ Noe. Hij maakte een stal. Toen klaar was zijn stal, pakte hij menschen op, en stalde die. En toen hij er al veel had binnengeloodst. bracht hij ze naar de vaste wal van Sumatra. Gekomen daar op de vaste wal, verkocht hij hen van land tot land. Toen die op waren, keerde hij weer herwaarts naar Simoeloel. Hij vatte weer menschen op, en sloot hen weer in de stal. Kwam er een schip van de vaste wal, dan verkocht hij hen daaraan. Aldus ging het maar voortdurend. Onderwijl kwam er een teungkoe van de vaste wal. Met zijn hoevelen was de teungkoe? Met zijn tweeën met zijn panglima Marahabit. De teungkoe sprak tot den grootvader van Datoes $\mathrm{Nja}^{\text {s }} \mathrm{Noe}$, wat zeide hij? "Je moet niet die menschen verkoopen! Ik mohammedaniseer dit land. De soeltan van Atjèh heeft gezegd, dat zulks kon strekken ter vervanging van mijn bedevaart. De soeltan van Atjèh heeft gezegd, dat deze menschen al tot den laatsten man het bosch in waren gegaan.» Onderwijl ging de teungkoe de menschen uit het bosch verzamelen. Hij trof hen aan, nam hen mee naar de kampong. Hier gekomen, huisvestte hij hen in een kamer, hij sloot die af; en ging weer menschen verzamelen. Achter zijn rug ging de grootvader van Datoe ${ }^{5} \mathrm{Nja}^{5}$ Noe de menschen halen die hij had gehuisvest in de kamer. Hij plantte lansen daar beneden, hij wierp van hier de menschen naar daar op de punten van de lansen, en allen vonden den dood. Daarop kwam de teungkoe, hij zeide tot den grootvader van Datoes $\mathrm{Nja}^{\text {s }}$ Noe: "Je moet niet dooden de lieden die ik heb ver- 
zameld!» Hij wilde niet hooren. Toen kwam zijn panglima, en hij en de grootvader van Datoe $\mathrm{Nja}^{5}$ Noe twistten; zij twistten, en Panglima Marahabit werd boos. $\mathrm{Zij}_{\mathrm{ij}}$ worstelden hij en de grootvader van Datoe ${ }^{5} \mathrm{Nja}^{5}$ Noe. Vermoeid van het worstelen hier op de vaste wal, gingen ze worstelen in zee. Het lukte aan een steen te binden de haren van den grootvader van Datoe $^{5} \mathrm{Nja}^{\mathrm{s}} \mathrm{Noe}$, zoodat hij niet kon opstaan. Daarop ging Panglima Marahabit terug naar hier aan wal. Achter bleef hij daar in het water. $\mathrm{Na}$ drie nachten ging men kijken, toen leefde hij nog, hij was niet dood, en omgekeerd was de steen. Toen vroeg hij vergeving aan panglima Marahabit. De panglima zei: "Als ge luistert naar wat ik zeg, maak ik u los. Is het dat niet ge luistert, moge ge dan sterven in het water, en ik maak je dan niet los.» Wat zeide daarop de grootvader van Datoe $^{5} \mathrm{Nja}^{5}$ Noe? "Als ge mij verlost, zal ik geen menschen meer dooden. Dat is o panglima mijn verzoek als je belieft aan U: maak mij los!» Hij maakte (hem) los. Hij keerde naar hier aan land terug, hij ging naar zijn huis. En hij doodde niet (meer). Zoo werd dan het land door den teungkoe geislamiseerd. Nadat het land was geislamiseerd geworden, keerde de teungkoe terug naar Atjèh. Gekomen in Atjèh, zocht hij den soeltan van Atjèh op. Wat zeide hij tot den soeltan? "Het land waarover ge met mij spraakt ben ik wezen islamiseeren. Dat is wat ik u rapporteer o soeltan van Atjèh.» Wat zeide de soeltan van Atjèh? "Goed, het is niets. Maar keer terug. Hier is een paal. Breng die naar de baai van Simoeloel. Maak na aankomst daar een moskee. Hebt ge die straks voltooid, vestig dan den godsdienst, en vestig de adat in het land. Vervolgens keerde hij herwaart naar de baai van Simoeloel. Hier aangekomen voltooide hij de moskee. Toen klaar was de moskee, stelde hij aan imam, chatib, en bilal, als hoofden van de gemeenteleden. En toen zij er waren die de zaken van den godsdienst hadden te bestieren, stelde hij wereldsche hoofden aan. Hij schiep twee radja's, twee malintang's, en één hoofd voor de vreemdelingen.

Bovenstaand verhaal teekende ik op uit den mond van Datoe Lambasét, een nazaat van Datoes Aloeajan.

Het tegenwoordige hoofd van het geslacht Toefa: Datoe Lěpés, wonende te Laoe rěs 
een dezelfde stof behandelende "tambo", gesteld in een van Simaloereesche, Atjèhsche e. a. smetten geenszins vrij Maleisch.

Die tambo loopt aldus:

\section{Alamat.}

Inilah katrangan asal oesoel moela dahoeloe mendjadi adat dengan hoekoem dalam negri Simaloer, soerat sarakata, soepaja masaloem orang simoeanja atawa orang Koempeni, soepaja trang asal orang djadi datoe pamoentja $^{5}$ dalam negri Poelo Simaloer adanja.

Moela $^{2}$ asal dahoeloe datang satoe orang kadalam ini negri, bernama Toeankoe Sianos Kares Mati, dia tinggal di Oedjoeng Toeba. Djadi dalam itoe datang satoe orang bernama Soemareh Bintol. Itoe orang dia tinggal di Along. Djadi bertemoe itoe orang doea. Dia moepakat, dia maoe prang ini negri, sebab ada satoe orang bernama Lafoeng Lasali, itoe orang peuhoekom kras. Djadi dia maoe prang orang. Djadi berdjalan itoe orang doea dari Oedjoeng Toeba pergi ka Simaloer, dia bawa doea ekoer kambing. Sampai di Simaloer pigi dia lihat Lafoeng Lasali, dia tinggal di Doloe. Sampai di Doloe itoe Lafoeng Lasali tidoer dalam ajoen. Djadi dia tanjai: "Siapa ini?» Djadi orang sitoe bilang: "Anas Lafoeng Lasali.» Djadi poelang itoe orang doea, dia moefakat, dia ambil satoe kambing, dia bikin pakajannja amas sama sekali, sampai berat dia poenja badan amas semoeanja. Djadi dia lepas itoe kambing berdjalan. Sampai di Taloe $^{s}$ Simaloer, Lafoeng Lasali tangkap itoe kambing, dia boenoeh, dia ambil semoeanja dia itoe emas. Djadi nene Datoe $^{s}$ Pamoentjas tjari itoe kambing, - tidas ada lagi! Djadi sampai dia kasih chabar kepada Lafoeng Lasali: "Dari kami poenja kambing, soedah hilang dalam kamoe poenja negri. Dari itoe arta, tida ${ }^{5}$ boleh hilang, boleh poelang! Lasali periksa! Kalau tida $^{5}$, ini negri kami prang.» Djadi nene ${ }^{5}$ Datoe $^{5}$ Pamoentjas prang itoe negri. Lama ${ }^{2}$ prang, mati orang berapa banja ${ }^{5}$, djadi Lafoeng Lasali minta tolong pada nene ${ }^{5}$ Datoe $^{5}$ Landasan, dia

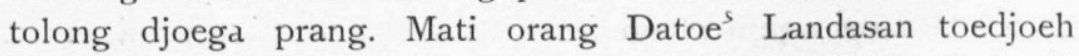
orang, djadi dia bikin damei itoe prang. Soedah baik, dia kasih negri sabelah kepada nene $e^{s}$ Datoes Pamoentjas. Dari Koeala Simaloer nene ${ }^{s}$ Datoe $^{s}$ Pamoentja $^{5}$ Ratoes poenja prentah; poelang kepada Datoes Landasan sabelah Bahoeng, dia jang prentah. Djadi datang nenes Datoes $\mathrm{Nja}^{\mathrm{s}} \mathrm{Noeh}$, dia tangkap orang, dia 
djoeal semoeanja. Djadi kemoedian datang Teungkoe Kramat di Oedjoeng, dia bilang: "Kita bikin adat dengan hoekoem dalam ini negri. Itoe orang djangan didjoeal lagi. Saja bikin islam orang semoeanja.» Djadi ada adat dengan hoekoem dalam ini negri. Djadi poelang Teungkoe Kramat ka Atjeh. Bertemoe dengan radja Atjeh, dia bilang: "Semoeanja soedah saja islamkan itoe negri.» Djadi radja Atjeh bilang: "Kalau begitoe, bawa dia sini itoe orang poelo barang doeapoeloeh; boleh saja lihat jang djadi radja, soepaja boleh tetap dalam itoe negri.» Djadi poelang ka negri poelo Teungkoe Kramat. Dia bawas nene ${ }^{s}$ Datoe $^{5} \mathrm{Nja}^{s}$ Noeh satoe orang, nene $e^{s}$ Datoe $^{s}$ Pamoentjas Ratoes satoe orang, jang lain ada lagi ampatpoeloeh orang, semoeanja pigi di Atjeh, bertemoe dengan radja. Jang lain habis mati semoeanja, tinggal tjoema doea orang sadja: nene ${ }^{5}$ Datoe $^{5} \mathrm{Nja}^{5}$ Noeh satoe orang, nene $^{s}$ Datoe ${ }^{s}$ Ratoes satoe orang. Djadi radja Atjeh oedji itoe orang doea. Nene ${ }^{5}$ Datoe ${ }^{5} \mathrm{Nja}^{5}$ Noeh dia bikin dalam meriam, toedjoeh hari, tidas mati, dia kasih kaloear. Nene ${ }^{5}$ Datoe $^{5}$ Ratoes dia labang di batang kajoe besar, toedjoeh hari, tida djoega mati, habis dia lepas. Radja Atjeh bilang: "Inilah boleh djadi radia kita bikin. sebab boleh tahan nedii. Diadi nene $e^{5}$ Datoe ${ }^{5}$ Ratoes bilang: "Toeankoe Ampon, djangan saja bikin djadi radja. Ada jang lain, karena saja djadi badal sadja.» Radja Atjeh bilang: "Kalau begitoe bawas disini itoe orang, boleh saja lihat. Djadi poelang ka negri poelo itoe orang doea. Sampai di poelo, moefakatlah itoe orang, maoe pigi lagi di Atjeh, antar persembahan. Disoeroeh nene $\mathrm{s}^{\mathrm{s}}$ Datoe $^{\mathrm{s}}$ Langkadeh, dia tida maoe pigi. Nene $e^{s}$ Datoe $^{s}$ Ratoes bilang: "Kalau kamoe pigi, kamoe djadi radja.» Dia tida ${ }^{5}$ djoega maoe pigi. Dia bilang nene Datoes Ratoes: "Pigilah, biar saja djangan djadi radja.» "Kalau moengkir achir kemoedian, begimana?» Sampai dia bersoempah nene $^{s}$ Datoe $^{s}$ Langkadeh: "Kalau saja engkar sapandjang kita poenja djandji, saja djangan selamat doenia achirat! Biar saja boeta! Saja djanganlah djadi radja dalam ini negri!» Habis itoe perchabaran pigilah nene ${ }^{5}$ Datoe ${ }^{5} \mathrm{Nja}^{5}$ Noeh dengan nene Datoes Ratoes, pigi hantar itoe persembahan. Sampai di Atjeh, bertemoe dengan radja. Djadi dia kasih persembahan kepada radja. Djadi radja pechabaran: "Kalau begitoe, biar saja bilang nene $^{s}$ Datoe $^{s} \mathrm{Nja}^{s}$ Noeh djadi radja negri Simaloer, nene $e^{s}$ Datoe Ratoes djadi pamoentja ${ }^{5}$ dalam negri Simaloer.» Habis dia sampai ka poelo, dia bikinlah atoeran dalam negri: Orang lima soekoe: 
satoe soekoe Dagang itoe Datoe ${ }^{5} \mathrm{Nja}^{5}$ Noeh, satoe soekoe Toefa itoe Pamoentjas Ratoes, satoe soekoe Lasali itoe orang poenjá, satoe soekoe Bolawah itoe Pamoentjas Bandjar, satoe soekoe Bolawah itoe Pamoentjas Bandjar, satoe soekoe Kaboe, itoe jang djadi imam Datoes Langkadeh. Soepaja trang adanja. Ini soerat tjalitra dari nenes mojang toeroen kepada ana tjoetjoenja perchabaran, bersalin ana'nja. Soepaja ma'loem orang simoeanja saperti perchabaran ini jang tertoelis dibawah ini. Soerat tamat kalam. Amin!

Datoe $^{\text {s }} \mathrm{Nja}^{\text {s }} \mathrm{Ta}$ van soekoe Kaboe, neef van den Datoe Langkadéh uit de tambo en, als deze, afstammeling van den na te noemen Datoes Mantawaj, was het met beide bovenstaande texten oneens en gaf $\mathrm{mij}$ een derde, voor zijn geslacht meer voordeelige lezing:

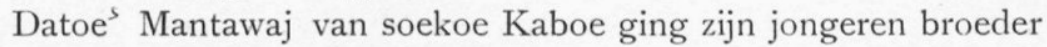
Bèhoea zoeken. Op zijn omzwervingen kwam hij tot Pangaroesan, waar een boomstam de vaart versperde. Datoes Mantawaj kapte den boomstam weg. Hij was daar nog mee bezig, toen kwam Si Toefa, die broederschap met hem sloot, en verklaarde, Datoe $^{s}$ Mantawaj steeds te willen volgen. Samen trokken zij verder en kwamen tot Simoeloel. Daar tuigden zij een bok op met gouden tuig, en lieten dien los. De landsvorst Lafōng Lasali, het dier ontwarende, doodde den bok en nam het goud. Datoe $^{\text {s }}$ Mantawaj en Si Toefa hadden hun doel bereikt: $\mathrm{Zij}$ hadden een voorwendsel om Lafōng Lasali te beoorlogen. Deze verloor den strijd en riep de hulp in van Datoe ${ }^{s}$ Aloeajan, die de vrede herstelde. Datoe ${ }^{s}$ Mantawaj kreeg de helft van het rijk, en Lafōng Lasali stond de hem resteerende helft af aan Datoe $^{\text {s }}$ Aloeajan. Datoe ${ }^{s}$ Mantawaj had een dochter, die hij uithuwde aan zijn vriend Si Toefa. Ook had hij een zoon Datoe Kaha. Toen kwam er bevel van Atjèh's soeltan, om geschenken en een gezantschap te zenden. Si Toefa trok naar Atjèh, en zag zich beloond met de toezegging, dat hij zijn schoonvader zou mogen vervangen in het bestuur over diens landschap; maar na zijn dood moesten Datoes Mantawaj's afstammelingen weer gaan regeeren. Sindsdien bleef echter het bestuur in $\mathrm{Si}$ Toefa's geslacht, vanwaar voortdurende oorlogen tusschen de soekoe's Kaboe en Toefa. Nazaten van Si Toefa, Datoes Mantawaj, Lafōng Lasali, en Datoes Aloeajan waren resp.: Si Lěpés van soekoe Toefa, Datoe $\mathrm{Nja}^{5} \mathrm{Ta}$ van soekoe Kaboe, Panglima 


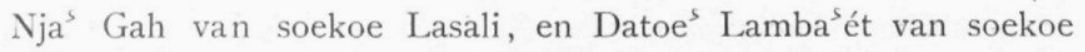
Bòlawa.

Inafi-nafi Toeankoe Manggarang.

Nga sara Toeankoe Manggarang èrè, banònè tè Poelò Banjas, mamòti-mamòtijah mè $\mathrm{Lo}^{s}$ Simoeloel. Lentōo ia $\left(\mathrm{e}^{s}-\right) \mathrm{ba}^{s} 1 \overline{\mathrm{o}}^{s}$, nipanggél sagalò radjò-rađjò, léngnè: " $\dot{\mathrm{E}}^{\mathrm{s}}$ dès $\overline{\mathrm{o}}$ èrè, nga ${ }^{s} \overline{\mathrm{O}}$ fěsang $\mathrm{e}^{s}$-bacha $a^{s}$ banòmèrè, mièna èna $a^{s} a^{s} \bar{o}$. Balandjò ba $a^{s}$ doemòn si wabés. Miba-miba an ndō.» "Dai, sadò si-nga dapè maiba anmò.» "Doemasar tiò -tiò wakětoe mangan tanaseun an toeankoe èrè!» Saò-saò ratoe $^{5}$ mina ${ }^{5}$ eun saò ingkan lajap. Sara falal tè-dò ${ }^{s} i$ mèsa ratoe ${ }^{s}$ èdè, ratò-ratò mangěba annè. Matoeasi $\mathrm{sa}^{5} \mathrm{a}$ dana eun annèja, lěpaj ${ }^{5}$ ataj $^{5}$ balal, nintoe ${ }^{5}$ sira, mèlafě la òn, nintō marō sira. Oewi-oewi mangi mamasét-masét. Alènè toeankoeja mè sira è angkal, mè běsilè̀. Niram sira ana Teungkoe $e^{s}$ Oedjoeng, maè ja mè-ròsi iléq daja, mangèna si-nga besilè ${ }^{s} i a$, niafén-afén silès daja. Matoeasi sa ${ }^{s} a$ niïla běsilè ia ana $^{5}$ toeankoeja, nitidaò $\mathrm{sa}^{5} \mathrm{a}$ kapoetoesan silè ${ }^{5} i a$. Léngda alè toeankoeja: "Ba doemòn maiila kapoetoesan silè"s. Nè toetō" mè-ròs $\mathrm{i}_{\mathrm{i}} \mathrm{e}^{\mathrm{s}}$ Toeankoe Manggarang." Léngnè sasa: "Rai, dèman

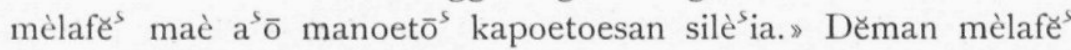
$\mathrm{sa}^{5} \mathrm{a}$ maèja ana ${ }^{5}$ Toeankoe $\mathrm{e}^{s}$ Oedjoengia; lento $\mathrm{o}^{5}$ dò $^{s} \mathrm{i}, \operatorname{ninto}^{-5}$ ana toeankoeja. Léngnè : "Daifa $a^{s} \bar{o}$ moentōos! Mali $a^{s} \bar{o}$ manoetōo kapoetoesan silè $\mathrm{e}^{s}$ diò, toeankoe òj. Nga ${ }^{s} \bar{o}$ daroeròn alèmòja, léngda: Nè toetōo mè-rò ${ }^{s} i$ toeankoe kapoetoesan silè ${ }^{s}$ ia. Doema ${ }^{s}$ ar ngang $a^{5} \bar{o}$ mèria; moeatoe $e^{5}$ dè $^{s} \bar{o}$ kapoetoesan silè $\grave{e}^{s}$ ijè. » Niahan toeankoeja: " $\mathrm{Ba}^{\mathrm{s}}$ doemòn wila kapoetoesan silè"s. Anadō-èněng ò barani la $a^{s}$ òn manoeto $\overline{0}^{s}$ kapoetoesan silè ${ }^{s}$ ? Doema $a r$ moeatoe atang $\mathrm{e}^{\mathrm{s}}$ dè $\mathrm{e}^{\mathrm{s}}$, sěbab diò si mangila!» Léng ana ${ }^{\mathrm{s}}$ Toeankoe è Oedjoengia: " $\mathrm{Ba}^{s}$ doemòn wila! Ėneng-atang oetoeto ${ }^{s} \mathrm{e}^{\mathrm{s}}$ diò Toeankoe òj. Atěrě $a^{s} \bar{o}$ kapoetoesan silè ijè.» Niahan toeankoeja: "Tamè-isès angkal, doe sò oepantjōng. Malawan ò la òn manoetōs kapoetoesan silè ${ }^{s}$; salangaj-oelangaj tè diòi bahaj sira oetasoeti.» Léngnè: "Rai toenkoe òj, bětanggoe $a^{s} \bar{o} \mathrm{e}^{s}$ diò arěgò dòfòngi. Sènoe $e^{s}$ pantjōng mang $a^{s} \bar{o}$ ngang lěntōo dòfòngi.» Niòlěng sa $a^{s} a$, $a^{s} a^{s}$ Toeankoe $\grave{e}^{s}$ Oedjoengia mè loema. Lentōo dò loema niatoe $^{s} \grave{e}^{s}$ ajanèja léngnè: "Bè aja òj, $\mathrm{e}^{s}$ dè ${ }^{s} \bar{o}$ èrè, aga ${ }^{s} \bar{o}$ ngang lěntōo oemòr ${ }^{s} \bar{o}$, nifoenoe $a^{s} \bar{o}$ Toeankoe Manggarang, sěbab nga ${ }^{s} \bar{o}$ manoetōo kapoetoesan silè $e^{s} \grave{e}^{s}$ isè. Ngang ja soeè toeankoejah, léngnè: Oepantjōng s̀ò $e^{s}$ diòì!» Léng sasa Teungkoe $e^{s}$ 
Oedjoengia: "Ngang wahan $e^{s}$ diò ina èrè : béré mè-ròs $i$ ès $-i l e ́ s$ Toeankoe Manggarang èdè! Mahaò pè'èlnè. Sènoes nifoenoe sò toeankoe èdè! Maè masò; djangennta ${ }^{5} i$ moefoeha! Aradōlia, ba s̀̀ nifoenoe! Widjinkan inènawamò.» Oeměnggés sasa ana Toeankoe ès Oedjoengia: "Dai aja òj, bas ō nifoenoe Toeankoe Manggarang èdè!» Lěntōs djandjija si-nga dòfòngija, maè ja $\mathrm{sa}^{5} \mathrm{a} \mathrm{ana}^{5}$ Toeankoe è $\mathrm{e}^{\mathrm{s}}$ Oedjoengia; nisěba ajanèja èlè inanèja. Lěntō $\bar{~}^{s}$ a ès bintoe, niaòngania inanèja, léngnè: "Alé měněng dia ana òj, dō watoe è $^{s}$ diò kapoetoesan silè'ia. Ngang niatoe $\grave{e}^{s}$ dès $\bar{o}$ ajamò satěpé.» Niòlěng sa $\mathrm{s}^{s} \mathrm{a}$ mè loema, nisěba inanèja, niatoe $^{s} \mathrm{sa}^{s} \mathrm{a}$ kapoetoesan silè $\mathrm{s}$ ia. Ninaoeng ndō sa's maè anas Toeankoe ès Oedjoengia, mè mamoefoej djandida èlè ${ }^{s}$ Toeankoe Manggarangia. Lěntōs $\mathrm{sa}^{s} \mathrm{a}$ dòs $\mathrm{i} \mathrm{è}^{\mathrm{s}}$-ilés Toeankoe Manggarangia, léngnè: "Ngang $a^{s} \bar{o}$ fěsang Toeankoe Manggarang òj. Pantjōngěng $\mathrm{a}^{5} \overline{\mathrm{oj}}$. Ara si moeda $\mathrm{e}^{\mathrm{s}}-$ dèta $^{5} \overline{\mathrm{o}}, \mathrm{ba}^{5}$-doe mengapò, naoemang. Ba rasòb saò lěbangi banòng $\bar{o}$, oemalòri masaél mamantjōng $\grave{e ̀}^{5}$ dès $\overline{0}$.» Léng Toeankoe Manggarangia sa ${ }^{5} a$, léngnè : «Dai, misòb lěpoel èdè, misòfan ia dònès aléng-aléngnè, oemalòria oepantjōng.» Dasòb sa'a lěpoelia, daba ja sasa mè-ròs $i$ $\grave{e}^{s}$-bahas oetoe $^{s}$ ia, dasěfan dònès aléng-aléngnè. Matoeasi sasa niabés Toeankoeja bědangnè, niba $\grave{e}^{s}$ boeanglimanè, léngnè: "Pantjōngia anas'da èdè.» "Daï Toeankoe òj, dō oesoebò oepantjōng.» Nipantjōng sasa, bas dai sna nipantjōng. Ngang ia asělò mamantjōng, niba sasa $\grave{e}^{s}$ Toeankoe Manggarangia bědangia. Nipantjōng $\grave{e}^{s}$ Toeankoeja sasa ataja, ba $^{s}$ dai maroe sna. Ngang ia asělò mamantjōng ana ${ }^{s}$ Teungkoe $e^{s}$ Oedjoengia, léng Toeankoe Manggarangia: "Dai $\mathrm{fa}^{\mathrm{s}}$ s̀ oefoenoe, tasaboei ita malahi. Ahimas ${ }^{s}$ '̀, tès doenia lentōo $\grave{e}^{s}$ achirat. Oeba s̀̀ amada sagalò padagangan; radjòda s'̀̀ padaganganja. Dès $\bar{o}$ manidaò tènès bangoeloe èlès pamoentjas $\mathrm{è}^{s}$-bahas banò èrè.» Lěnto ${ }^{s} \mathrm{sa}^{s} \mathrm{a}$ balal Diměsat, kalnear sa a Toeankoe Manggarangia mès masihét, mamoeha sagalò radjò-radjò, mangatoes ia $\grave{e}^{s}$ radjò-radjòja , léngnè: "Nga sara ata èrè, anas Teungkoe ès Oedjoeng, oewabés ia ahéng $^{s}$ gō; oeba ja radjòda sagalò padagangan si fěsang tè lòr, namònè Datō ${ }^{s}$ Dagang.» Léngda sa a radjò-radjò ès -bahas banò : "Dai Toeankoe òj. Nga-mang lentōos pikérmò, ba ${ }^{\text {s }}$ dō mangapò, tatoes è $\mathrm{e}^{s}$ ajanèja , Teungkoe ès Oedjoengia.» Matoeasi $\mathrm{sa}^{s} \mathrm{a}$ maè sira mangatoe $\mathrm{e}^{s}$ mè-ròs $\mathrm{i} \mathrm{è}^{\mathrm{s}}$ Teungkoe ès Oedjoengia; léngda: "Djami ès -èrè mamoeha $\mathrm{è}^{s}$ diò, nga manidaò Toeankoe Manggarang è diama ${ }^{s}$ i sagalò radjò-radjò mangěbaja datōos dagang;

Dl. 71 . 
ana ${ }^{s}$ òja moeba, tidaònè $\grave{e}^{s}$ diò.» Léng Teungkoe $\mathrm{e}^{s}$ Oedjoengia: " $\mathrm{Ba}^{s}$ dai ${ }^{s}$ ana $\mathrm{a}^{\mathrm{s}} \mathrm{ja}$ mara $\mathrm{da}^{s}$ adat $\mathrm{e}^{s}-\mathrm{baha}^{\mathrm{s}}$ banò , sěbab lélés adjing ${ }^{5} \mathrm{o}$ banò èrè ; $\mathrm{ba}^{\mathrm{s}} \mathrm{dai}^{\mathrm{s}}$ nian adat, sěbab alal haram pěrkadja an ana ${ }^{s}$ banò. Nga-mang sènoe ${ }^{s}$ si-nga sala ana ${ }^{s}$ banò nisalakan, - ba $\mathrm{ba}^{\mathrm{s}} \mathrm{dai}^{\mathrm{s}} \mathrm{e}^{\mathrm{s}}$ dè $\mathrm{e}^{\mathrm{s}} \mathrm{h}, \mathrm{ba}^{\mathrm{s}}$ oeba mara $\mathrm{da}^{s}$ adat jè.» Léng $\mathrm{sa}^{5} \mathrm{a}$ Toeankoe Manggarangia: $\mathrm{Ba}^{5}$-doe mangapò! dai $\mathrm{fa}^{\mathrm{s}}$ ia mangansala ana banò; dònè doel aloeanda padagangan měmoeha radjò banò.» Léng sasa Teungkoe $\mathrm{e}^{\mathrm{s}}$ Oedjoengia: "Dai masa toeankoe òj, ba doe salanè masa.» Ngang sa a mandjadi datoe dagang kirò-kirò nga sataōn ia mandjadi datoes dagang ia, nga-mang si-nga sala ana ${ }^{s}$ banò. Matoeasi sasa ahěsi Teungkoe $\mathrm{è}^{\mathrm{s}}$ Oedjoengia: "Nga wahan ana $\mathrm{o}^{\mathrm{j}}$, béré mara $\mathrm{da}^{5}$ palènta banò, mandjadi dòsò pěrkadja anmò èlè $\mathrm{e}^{5}$ ana banò, moesalakan sira mè-isè mè-ria. Doema ar ba ${ }^{5}$ daï sò datoes dagang." Léng ana nèja sa $\mathrm{sa}^{5}$ : "Nganga $\mathrm{ba}^{5}$ dai $\mathrm{ia}^{5} \mathrm{ma}$ aja òj, oetarén banò èrè; oehaj' amè wènèngi èlès inangsgō bé aja òj; manarén $\mathrm{a}^{s} \bar{o}$ banò, mè $\mathrm{a}^{s} \bar{o}$ banòn Malajoe.» Léng sa $\mathrm{s}^{\mathrm{s}}$ Teungkoe $\mathrm{e}^{s}$ Oedjoengia: "Daï ana òj! $\mathrm{Ba}^{s}$-doe-mòn ita boelawan tji daï balandjòmò. Si-nga doel nga sakati boelawan, tabagi tigò: sabagi mès inamò, sabagi mès dèsō, sabagi mès diò. Koerasan saò taba bagi inamò; kitab saò abés bagimò: toengkès tantarén ès dèsōh.» "Daï aja òj! Mitoesas $a^{s} \bar{o}$ èlè idjinmè èlès inangsgō." "Daï ana òj, maitoes as ò èlè idjinmasi. Salamat ò, salamat ami, tènè doenia lentō $\overline{\mathrm{e}}^{\mathrm{s}}$ achirat!»

Het verhaal van Toeankoe Manggarang.

Er was een gestrenge toeankoe, thuisbehoorend op de Poelo $\mathrm{Banja}^{5}$, die aan kwam zeilen naar de baai van Simoeloel. Aangekomen in de baai riep hij de vorsten en zeide: $4 \mathrm{Ik}$, ik ben gekomen hier in uw land om wat rond te kijken. Geld heb ik niet meegebracht. Gij geeft mij dus te eten.» "Goed, zooveel als er valt te krijgen geven we $u$ tot uw voedsel (antwoordden de vorsten, en onder elkaar zeiden zij:) "Nu zullen we iederen etenstijd voedsel schaffen voor dezen toeankoe!» Per vorst viel er op te brengen een bord gekookte rijst, en iederen dag had een andere vorst de beurt, en allen gelijkelijk schaften zij eten. Wanneer ze dan het eten brachten, als de zon al hoog stond, dan sloeg hij hen, en was het heel vroeg in den morgen, dan sloeg hij hen ook. Zoo ging het maar altoos door. Des toeankoe's gezellen gingen aan land om te schermen. De zoon van Teungkoe 
di Oedjoeng zag het, en ging erheen in hun nabijheid, om te kijken naar het schermen, en hij volgde hun schermen na. Ten slotte kon teungkoe's zoon schermen, en hij vroeg de eindwetenschap van het schermen. Des toeankoe's makkers zeiden: *Wij kennen niet de eindwetenschap van het schermen. Ga ze vragen daar aan Toeankoe Manggarang." Hij zeide daarop: "Goed, morgen ochtend ga ik vragen de eindwetenschap van het schermen.» Den volgenden morgen ging de zoon van Teungkoe di Oedjoeng; en aangekomen sloeg hij (T. M.) des teungkoe's zoon. Deze zei: "Ge moet me niet slaan! Ik kom vragen de eindwetenschap van het schermen aan u o toeankoe. Mij is 't gelast door uw makkers, zij zeiden: Ga vragen daar aan den toeankoe de eindwetenschap van het schermen. Thans ben ik hier gekomen; zegt U mij nu die eindwetenschap van het schermen.» De toeankoe zeide: "Ik ken die eindwetenschap van het schermen niet. Hoe kom je zoo óvermoedig vragen naar de eindwetenschap van het schermen? Nu zul jij ze mij zeggen, want jij kent ze!» De zoon van Teungkoe di Oedjoeng zeide: "Ik ken ze niet! Daarom juist vraag ik ze aan u o toeankoe. Leer mij die kapoetoesan silès.» De toeankoe zeide: "Laat ons aan wal gaan, ik zal je onthalzen. Je bent al te brutaal met je gevraag naar die kapoetoesan silès; daarenboven van jou ben ik nog niet bang." Hij zeide: "Goed toeankoe, maar ik vraag u twee nachten uitstel. Dan onthals mij maar als die twee nachten om zijn.» Hij keerde huiswaarts, de zoon van den teungkoe van de oedjoeng. Thuisgekomen sprak hij tot zijn vader: "O vader, wat mij aangaat, ik geloof dat mijn levensdagen geteld zijn, doordien Toeankoe Manggarang mij zal dooden, omdat ik hem gevraagd heb om de kapoetoesan silè ${ }^{s}$. Hij is toen boos geworden de toeankoe, en hij heeft gezegd: Jou zal ik onthalzen!» De teungkoe van de Oedjoeng sprak: "Ik heb je vroeger al gezegd: ga niet in de buurt van dien Toeankoe Manggarang! Boos is zijn inborst. Straks zal die toeankoe je nog dooden! Je bent toch gegaan; en daar heb je het nu al! Wat nu, laat hij u dooden! Ik geef je ziel verlof te gaan.» De zoon van Teungkoe di Oedjoeng weende: "Goed vader, laat die Toeankoe Manggarang mij dan maar dooden!» Toen vervuld was de overeengekomen termijn van twee dagen, vertrok de zoon van Teungkoe di Oedjoeng; hij groette zijn vader en zijn moeder. Gekomen aan de deur, riep zijn moeder hem terug, zeggende: 
«Kom even hier mijn jongen, opdat ik je meedeel de eindwetenschap van het schermen. Je vader heeft er mij zoo'n beetje van verteld.s Hij keerde in huis terug, begroette zijn moeder, en deze deelde hem mede de kapoetoesan silès. Toen ging hij weer heen de zoon van den teungkoe van de oedjoeng, om te vervullen de afspraak van hem en Toeankoe Manggarang. Gekomen daar bij Toeankoe Manggarang, zeide hij: "Ik ben gekomen o Toeankoe Manggarang. Onthals mij. Wat ge over mij bescheert, het komt er niet op aan, ga uw gang maar. Laten zij een gat voor mij graven, opdat het gemakkelijk zij mij te onthalzen.» Toeankoe Manggarang sprak: "Goed, graaft in gindschen grond (een gat), en plant hem daar in tot aan zijn middel, opdat ik hem onthalze.» Ze groeven in den grond, plaatsten hem daar in het gat, en plantten hem daar tot aan zijn middel. Daarop nam de toeankoe zijn zwaard, gaf het aan zijn panglima, en zeide: "Onthals dien knaap." "Goed toeankoe, laat ik eens probeeren.» Hij hiew, maar het lukte hem niet raak te houwen. Nadat hij zich moe had gehouwen, gaf hij het zwaard aan Toeankoe Manggarang. De toeankoe hieuw toen naar den mensch, maar ook hij vermocht hem niet te treffen. Vermoeid van het houwen naar den zoon van Teungkoe di Oedjoeng, zeide Toeankoe Manggarang: "Laat ik je niet dooden, laat ons zeggen dat we broeders zijn. Jij bent onze jongere broeder, van af de aardsche wereld tot in het hiernamaals. Ik stel $\mathrm{u}$ aan tot vader over de plaatsen der vreemdelingen; der vreemdelingen hoofd zijt gij. Zulks vraag ik aan de pangoeloe's en pamoentja's binnen dit land.» Den eerstvolgenden Vrijdag, ging Toeankoe Manggarang er op uit naar de moskee, om te ontmoeten de hoofden, en hij sprak tot de hoofden, zeggende: "Hier is een man, de zoon van Teungkoe di Oedjoeng, dien ik heb aangenomen tot mijn jongeren broeder; hem stel ik aan tot hoofd over de handelaren die van zee komen, met den titel datoe ${ }^{5}$ dagang., De landshoofden zeiden: "Goed o toeankoe. Als dat zoo bij $\mathrm{u}$ is opgekomen, 't is niets, deelen we dat dan mee aan zijn vader, Teungkoe di Oedjoeng.» Daarop gingen zij spreken met Teungkoe di Oedjoeng; ze zeiden: "Wij hier bezoeken u, omdat Toeankoe Manggarang ons hoofden heeft gevraagd een datoe ${ }^{\text {s }}$ dagang aan te stellen; sta daartoe uw zoon af, dat is zijn verzoek aan u.» Teungkoe di Oedjoeng sprak: "Mijn zoon zal geen adatfuncties bekleeden in dit land, want het is ter vervanging van mijn 
bedevaartsplicht dat ik werk in dit land; hij mag zich niet inlaten met de adat, want geoorloofd of verboden zijn de werken der landskinderen. Wanneer hij dan straks schuldige landskinderen bestraft, - ik zou het niet willen hebben, ik sta hem niet toe die adat te handhaven.» Toeankoe Manggarang zeide daarop: "'t Is niets! Laat hij dan geen straffen opleggen aan de landskinderen; laat hij slechts de vreemdelingen van de schepen hebben te brengen voor de landsgrooten.» Teungkoe di Oedjoeng zeide: "Goed dan Toeankoe, daar steekt geen kwaad in.» Ongeveer een jaar nadat hij datoes dagang was geworden, gebeurde het dat een landszoon misdreef (en terzake werd gevonnisd). Daarop werd Teungkoe di Oedjoeng boos: "Ik heb gezegd jongen, dat je je niet moest inlaten met de handhaving der landsinstellingen, want daardoor handel je zondig tegenover de landskinderen, hen bestraffend dan zus dan zoo. $\mathrm{Nu}$ mag je niet langer datoes dagang zijn.» $\mathrm{Zijn}$ zoon zeide daarop: "Als ik dat niet langer zijn mag vader, verlaat ik dit land; ik wil niet bij $u$ en moeder blijven o vader; ik ga het land verlaten, ik trek naar het Maleische land.» Teungkoe di Oedjoeng zeide: "Goed mijn jongen! Maar wij hebben geen goud om te dienen tot uw blandja. Er is slechts één kati goud, we deelen dat in drieën: een deel voor uw moeder, een deel voor $\mathrm{mij}$, en een deel voor jou. Een koran geven we aan uw moeder; een kitab neemt ge voor uw deel; en de overblijvende stut is voor mij." "Goed vader! Laat mij dan vrij met Uw beider verlof van u en van mijn moeder." "Goed mijn jongen, wij laten u vrij met ons beider verlof. Het ga u wel, en het ga ons wel, van deze wereld tot in het hiernamaals!»

\section{Banta Berransah. ${ }^{1}$}

Nga sara radjò èrè, kahannè Èsěkandar Ali, ana'nè Banta Berransah, siantěngan Banta Kĕrta. Matoeasi sasa měrěsia radjòja, ajanè Banta Běransaja. Běsang inanè Poeti, matoeasi niatoe ${ }^{s} \dot{e}^{s}$ ana'nèja: "Tòtò oj, alé! Nga měrěs ajamò. Alé mònia soengkoel. Danengia la òn merrě !, Matoeasi sas maèja anas nèja. Ntōo dòsi nisoengkoel ajanèja. Matoeasi soeès ia: "Itaja rō si manoengkoel $\dot{e}^{s}$ dès ōwi?" "Dès ō aja oj. Anadō s̀̀ dan merrěs?" "Èněng $a^{s} \bar{o}$ sěbab dan merrěs, ngasō mènihi." Matoeasi sasa

1) Van de dus genaamde Atjèhsche hikajat wordt zeer bekort het begin hier weergegeven.

Dl. 71 . 
niětěj oeměnggés radjòja. Nitoetō anasnèja: "Anadō 's̀něng oeměnggés aja oj?» "Ijéngia! Nganga moeda manoeroei ${ }^{s}$ si

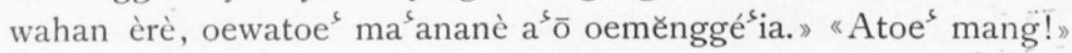
Léng ajanèja sasa: "Nga oewi masa nga i inihings'gō. Nga saè fanò èrè, nga ròs $i$ ès itafan lawi ${ }^{s}$ api, nga alès radjònè dòs $i$ banò sahōsi, baï tètaja kahannè; inama isjè radjòï èlès manòs-manòsnè , kahannè Malasōn Diri. Anasnè radjòï Noeroel Afela. Jéngia inihings'gōja. Nè toeroeis èlè $e^{s}$ adés mò Banta Kĕrta ?» Matoeasi $\mathrm{sa}^{s} \mathrm{a}$ maè sira manoeroeis inihi ajadaja. Dabés koedòda, mansarasira, malafén sagalò ra jat. Lěntōs dòs ${ }^{s}$ éténg dòtan, léng Banta Bĕransah: "Dai $\mathrm{fa}^{s}$ amè mali. Araò las'òn! Darò mang ami maè. Mitarén amè!» Matoeasi sasa mè sira anas radjòja. Dafoecha sara lalan sè-běl, dasét, dafoeha sangaōn ajōwajō sè-běl, nièna Banta Beransah èlès soerat ajowajōja, è ${ }^{s}$-bòntòr ajōwajōja èlè simpang dalania: mès ibilang sara, mès ènawan sara. Léng Banta Bĕransah: "Kakas òj, dalan èrè doea. Tasét doeanè. Òmè tala $\left.{ }^{\prime}\right)$ si moeda $\grave{e}^{s}$ diò?» « $\dot{\mathrm{E}}^{s}$ dès $\bar{o} \mathrm{~h}$ si oeda mè ènawan èrè $\mathrm{e}^{s}$ dèsōh.» "Daï masa, inama isè $b^{s}{ }^{s}-d \bar{o}$ moefoecha inihi ajantaja, inama isè sěnang ò.» Matoeasi maè ja Banta Kertaja, niásét dalannja. Araw-arawia nifoecha saò loema nènès Roebia. Ninaoe mantètèhĕm Banta Kĕrtaja. Niènas Roebiaja. "Òtaén dō s"ò?» "Tén $a^{s} \bar{o}$ isè nènès òj.» "Òmaè roe s̀̀ masa?» "Mè $a^{s} \bar{o}$ manoeroei inihi ajangs ō.» "Daïs masa. Bĕnging, naoeng měrěs $\dot{e}^{s}$ i. Berngija sasa mè ja bědjòdi. Matoeasi talō ja. Matòt masarès sarè $^{s}$ bahajannè, niòlěng mè-ròs loema nènès Roebiaja. Matasoe ja dònès $i e^{s}$ isèi. Mamòlěng sa a niséséw sa $a^{5}$ dò ${ }^{5} i$ Banta Beransaja: Maè ja sasa ès isèja, nifoeha sangaōn ajōwajō sè-běl, ngasi roea paò chabau, daětěj bětadōs. Matoeasi sa'a niras das Banta Bĕransaja: $b^{s}$-doe raï matas $\bar{o}$ bětadōs siraja. Maèngia sasa. Arawaraw ndō nifoecha si mamérét awén afòrat. Niětěj nitěmi. Matoeasi sa'a léng Banta Beransaja: "Andiòi afòrat awénmòja, moeětěj ma moetěmi? Moekoerangiaï, òré raï moesabòng!» $\mathrm{Ba}^{s}$-dō nipadoeli ataja. Maèngia sa'a Banta Beransaja. Dan-dan sasa nifoecha saò soerau. Nga ${ }^{5} i$ sara teungkoe, nga fětěng ia mangadji. Ninaoe $\mathrm{sa}^{5} \mathrm{a}$ mantètèhěm Banta Beransaja. Niènas $\mathrm{sa}^{\mathrm{s} a}$ teungkoeja, nitoetōo sasa: "Òtaén s̀̀ tòtò òj?» "Tén $a^{s} \bar{o}$ isè teungkoe òj." "Alé masa di as'loema, běnging, naoe merě ès i. » Běngi fanò nitoetōs

1) Dit tala ontmoette ik ook in ia èrè tala chèpèngmòja of ia talaš̀rè chépèng mòja, dat men mij gaf als vertaling van het Atjèhsche njòë (na) pèng gata. 
teungkoeja: "Itaja rō chachanmò?» "Kahan'ō Banta Běransah.» "Òmaè ò?» "Maè $a^{s} \bar{o}$ manoeroeis inihi ajangs $\overline{0}$. Nèhoe moeèngèl inihi ajangsōwi?» "Araja inihi ajamòï?» "Nga saò fanò dòsi tafan soebarang lawi ${ }^{s}$ api. Nga sara radjò dòs banò sahōi ${ }^{s}$ èlè manòs-manònnè, kahannè Malas ōn Diri; ana'nè radjòï Noeroel Afěla. Jéngia inihi ajang'sōï.» "Nganga jè, bas nèhoe wèngěl saoeměr ōh. Nganga oewis $\mathrm{ma}^{s} \mathrm{a}$, dai fa ${ }^{s}$ mennĕng ò maè. Ba měněng s̀̀ èsèrè, naoe měněng mangadji.» Òfélia'si, sataōn; ngang nila mangadji. Matoeasi sasa léngnè Banta Beransaja: "Mèngasō teungkoe òj! Daněng $a^{s} \bar{o}$ lasòn ès èrè.» "Daï mas a, naè-mang. » Maja sasa mèja dèta koedònèja. Dan-dan sasa loemalasòja, nifoeha saò blang, èlès loema dòsi tědè padangia. Mè niènas, sènga'i, sara nagò sè-běl. Niram sasa nagòja Banta Baransaja, galas ia: "Aléng mèria! Oewan sò t»

\section{Banta Bèransah.}

Er was een vorst, zijn naam was Iskandar Ali, zijn zoon heette Banta Beransah, de jongste Banta Kĕrta. Hij sliep de vorst, de vader van Banta Beransah. Kwam zijn moeder Poeti, zij zeide tot haar kind: "Jongen, kom! Je vader ligt te slapen. Ga hem toch wekken. Hij slaapt zoo lang!» Daarop ging haar zoon. Daar gekomen wekte hij zijn vader. Deze werd boos: "Wie is het die mij wekt?» "Ik vader! Waarom slaapt ge zoo lang?» "Dat ik zoo lang heb geslapen komt, omdat ik gedroomd heb. Daarop begon de vorst te weenen. Zijn zoon vroeg: "Waarom weent ge vader?» Dat is het! Als je wilt volgen wat ik zeg, vertel ik de beteekenis van mijn weenen.» "Vertel maar!» Zijn vader zeide: "Aldus was mijn droom. Er was een land, daar aan de overzijde van de vuurzee, en in dat land was een vorst, maar ik weet niet hoe hij heette; maar die vorst had een vogel, die den naam droeg Mala'ōn Diri. 's Vorsten dochter heette Noeroel Afla. Dat was mijn droom. Ga je ze opsporen met je broer Banta Kĕrta?» Daarop gingen ze volgen den droom van hun vader. $\mathrm{Zij}$ namen hun paarden, ieder een, en de onderdanen volgden hen. Gekomen aan den rand van het bosch; zeide Banta Beransah: "Gij moet niet gaan. Het is te ver! Wij gaan maar met ons beiden. Blijft gij achter!» Daarop gingen de vorstenkinderen. $\mathrm{Z} i \mathrm{ij}$ vonden een grooten weg, zij volgden dien, en zoo kwamen zij aan een grooten boom, en Banta Beransah zag aan dien boom een brief, en aan den voet van 
den boom splitste de weg zich: een weg ging naar links en een ging rechts. Banta Berransah zeide: «Broeder, deze wegen zijn twee. Volgen we ze alle twee. Welken weg kiest gij?» «Ik, ik wil graag den weg naar rechts.» "Goed, maar ge zult daar niet vinden de verwezenlijking van den droom van onzen vader, maar ge zult het gemakkelijk hebben.» Banta Kerta ging op weg, volgende het pad. Op eenigen afstand trof hij een huis van grootmoeder Roebia. Banta Kerta kuchte. Roebia keek op. "Vanwaar kom je?» "Ik kom van ginds grootmoedertje." "En waar wou je naar toe?» "Ik ga volgen den droom mijns vaders.» "Dat is mooi. Maar het wordt avond, ga hier maar slapen.» Des avonds nu ging hij dobbelen. En hij verloor. Toen hij al zijn kleeren kwijt was, keerde hij terug naar de woning van nènè ${ }^{s}$ Roebia. Tot zoover voor wat hem aangaat. Nu wordt er weer verhaald van Banta Berransah: Hij ging voort, en kwam aan een grooten boom, waarin hingen twee karbouwenbouten, die al maar tegen elkaar aanbonsden. Banta Berransah vatte ze beet: ze wilden niet ophouden met elkaar te vechten. Hij ging verder. Op eenigen afstand vond hij iemand die zwaar hout sprokkelde. Altijd deed hij er nog maar bij. Banta Beransah zei: \&Waarom terwijl je hout zoo zwaar is, doe je er maar altijd bij? Ge moest er wat afdoen, dan kon je het tillen!, De man gaf er niet om. Banta Bèransah ging verder. Na eenigen tijd kwam hij aan een soerau. Er was een teungkoe bezig uit den koran te reciteeren. Banta Berransah kuchte. De teungkoe keek op, en vroeg: "Waar kom je vandaan jongetje?» "Ik kom van ginds teungkoe." "Kom dan hier binnen, het wordt avond, slaap hier maar." 's Avonds vroeg de teungkoe: "Hoe heet je?» "Ik heet Banta Beransah.» "Waar ga je heen?» "Ik ga volgen den droom van mijn vader. Hebt ge ooit gehoord mijns vaders droom?" "Wat heeft je vader gedroomd?" «Er zou een land zijn aan de overzijde van de vuurzee. Daar is een vorst in dat land en die heeft een vogel, Mala'ōn Diri geheeten; de dochter van den vorst heet Noeroel Afla. Dat is de droom van mijn vader.» "Als dat het is, nog nooit van mijn leven heb ik daar van gehoord. Als de zaken zoo staan, moet je nog maar niet verder gaan. Blijf eerst hier, om te mangadji.» Hoe lang was het, een jaar; toen kende hij mangadji. Daarop zeide Banta Berransah: "Nu ga ik verder teungkoe! Al zoo lang heb ik hier verbleven.» "Goed, ga maar.» Te paard ging hij verder. 
Geruimen tijd was hij voortgegaan, toen kwam hij op een vlakte, en een huis stond daar midden in het veld. Hij ging kijken, wat daarin was, dat was een groote draak. Toen de draak Banta Beransah gewaar werd, was hij blij: «Kom hier! Ik eet je op!»

\section{Vordering namens $\mathrm{Nja}^{5} \mathrm{Kanda}$ tegen Si Kandang.}

Oenèn-oenèn mataj nènès $\mathrm{Nja}^{s}$ Kanda silaé, tantarén nènè nè silafaj. Matoeasi běsang toeònè Si Kandang, ba'dōja ana silaé, darò doel silafaj. Matoeasi sa'a hawélia èlè nènè ${ }^{s} \mathrm{Nja}^{s}$ Kandaja nènèsnè silafaj. Matoeasi sas a niabés ana'nè ajanè $\mathrm{Nja}^{s}$ Kandaja. Nihòkòt èlès kěbaò, nisaboeis ana'nè ajanè $\mathrm{Nja}^{s}$ Kandaja, niansimèngělan $\mathrm{e}^{s}$ ata. Matoeasi sa'a niamòlěng $\mathrm{è}^{s}$ ajanè $\mathrm{Nja}^{s}$ Kandaja sagalò aratònè, awas bònòl, èlè kěbaò, èlès inafa, èlès aloeman. Matoeasi $\mathrm{sa}^{\text {sa }}$ mataj ajanè $\mathrm{Nja}^{s}$ Kandaja. Inama isè daněng mamòlěng isè ngang aga ${ }^{s} \bar{o}$ ampèspoeloe taoen mamòlěng ès ajanè $\mathrm{Nja}^{s}$ Kandaja. Mataj ajanèja, niabés Si Kandang mamòlěng, lěngnè: " $\mathrm{Ba}^{5} \mathrm{~d} \bar{o}$ rai mès diò $\mathrm{Nja}^{6}$ Kanda òj. Ngang mataj ajamò, mamòlengěng $\mathrm{è}^{s}$ dés $\bar{o} h$ awa bònòlōja.» Matoeasi, $\mathrm{ba}^{5}$ niba, èrè ja? "Tarén ajang' $\overline{\mathrm{o}} \mathrm{si}$ oewila, ba $\mathrm{b}^{\mathrm{s}}$ oewila aratòmò Kandang òj. Inang èrè, nga haj ajangōja, bas'dō moeabés ; doemasar bas oeba.» Daōkōmi sagalò toesa-toesa: "Béré abés Kandang òj!» Bas dō nitani. Soedanè mèria Sinafang, datoe ${ }^{s} e^{s}$ Toean Boom. Niōkōmi. Matoeasi sasa nitoetō Toeania ès Datōs $\mathrm{Nja}^{s}$ Noe èlès Datōs Mbò èlè ${ }^{s}$ Datōo $^{s}$ Lěpé: *Ara òběn pěkaròdaï? ara mila? Dibasònè aratò aja $\mathrm{Nja}^{5}$ Kanda, si nibas isè ajanè." Dataě datōo $\overline{-d a t o ̄}^{s}$ ia: "Atiěr aratò ajanè Nja Kanda. Ára sěbab? Nja haj ia bědagang, ngang isè mangalònò awas bònòlia.» "Nga oewi masa, léng toeania sasa, "mamòlěng $\mathrm{e}^{s}$ $\mathrm{Nja}^{s}$ Kanda, bašeng dai mamòlěng Si Kandang. Miba èlès katarangannè, dibasònè mamòlěng $\mathrm{Nja}^{s}$ Kanda, basěng dai mès $\mathrm{Si}$ Kandang. Jéngia, ntōs dò Simoeloel, miamòlěng $\mathrm{Nja}^{s}$ Kanda.

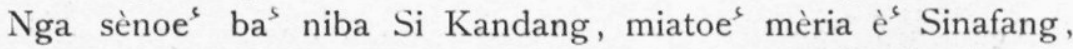
oemangòria oekoerōng. Ara sěbab? Maraboes ia Si Kandangi.» Ntōs dòsi Simoeloel, bašnōng niba Si Kandangia.

Eerst stierf de grootvader van $\mathrm{Nja}^{s}$ Kanda, achterbleef zijn grootmoeder. Toen kwam de oom van Si Kadang, hij had geen zoons, doch slechts twee dochters. Toen huwde hij met de grootmoeder van $\mathrm{Nja}^{5}$ Kanda. Toen nam hij tot zijn zoon 
aan den vader van $\mathrm{Nja}^{5}$ Kanda. Hij slachtte een karbouw, verklaarde zijn zoon te zijn den vader van $\mathrm{Nja}^{5}$ Kanda, en deed dat de menschen elkaar verstaanbaar maken. Toen dat was afgeloopen droeg hij over aan den vader van $\mathrm{Nja}^{5}$ Kanda alle zijn bezittingen, klappers, karbouwen, rijstvelden, en woonerf. Daarop stierf de vader van $\mathrm{Nja}^{\mathrm{s}}$ Kanda. Maar het is geleden naar mijn schatting veertig jaren dat e.e.a. kwam aan $\mathrm{Nja}^{5}$ Kanda's vader. Toen zijn vader was gestorven nam Si Kadang e. e. a. terug, hij zeide: "Jij krijgt de zaken niet $\mathrm{Nja}^{\text {s Kanda. }}$ $\mathrm{Nu}$ je vader is overleden, komen ze aan mij mijn klappers.» Uit, hij gaf ze niet, wat was het? «De nalatenschap van mijn vader (zijn ze) naar mijn weten, ik ken ze niet als uw bezit Kandang! Vroeger, toen mijn vader nog leefde, naamt ge ze niet; thans geef ik ze niet.» De ouderlingen berechtten de zaak: "Neem de zaken niet Kandang!» Hij luisterde niet. Het eind was dat men hier naar Sinabang kwam, en ze de zaak voorlegden aan den boomambtenaar. Hij sprak recht. Die heer vroeg aan Datoes $\mathrm{Nja}^{s}$ Noe en Datoes Mbò en Datoe ${ }^{s}$ Lépé: "Hoe is het met hun zaak? Weet gij dat? Volgens het zeggen zijn het de bezittingen van den vader van $\mathrm{Nja}^{5}$ Kanda, welke zijn vader hem had gegeven.» De datoe -datoe $^{s}$ antwoordden: «Inderdaad betreft het de bezittingen van $\mathrm{Nja}^{5}$ Kanda's vader. Waarom? Toen hij nog ongetrouwd was, verzorgde hij al die klappers.» "Als dat zoo is," zeide de toean boom, "moet alles aan $\mathrm{Nja}^{5}$ Kanda komen, en niet aan Si Kandang. Geeft terzake een bewijsstuk af, vermeldend dat alles overgaat aan $\mathrm{Nja}^{\mathrm{s}} \mathrm{Kanda}$, en niet aan Si Kandang. Dus, bij aankomst te Simoeloel, geeft ge alles terug aan $\mathrm{Nja}^{\text {s }}$ Kanda. En als dan Si Kandang de zaken niet wil geven, rapporteert ge dat naar hier te Sinabang, opdat ik hem dan opsluite. Waarom? Omdat die Si Kandang rooft.» Gekomen ginds te Simoeloel, stond Si Kandang de zaken niet af.

$\mathrm{R}$ a a d sels.

1. Nga sara taě-taě wèrè: "Mangan mantai-tai.» Taě, araja chachannè? - Mahoekoer fò nòl!

2. Nga haj saò takòs-takòs $\bar{o}$. Soebò takòs! "Oechoen-oechoen basdoe laoeng.» - Antěs manò !

3. "Mès - dèta $^{s}$ òlòrnè, mès-ōn lawélnè.» - Djanggoei

4. Nga haj ndō saò takò -takòsōja. Soebò takòs: "Nga saò bòn ajōojōo èrè, koeas ia mèria-sōn, dichawali mès -dètas." - Òlòl bělas tè taloeb. 
5, Nga haj saò takò̀-takò'ia. Soebò achan: "Nga saò fòn ajō-ajō, timboel ia dòsi banòn Malajoe.» Araja chachannè? - Mata balal.

1. Er is een raadsel als dit: "Eten al poepende.» Antwoord, wat is de naam ervan? - Het raspen van klappers!

2. Er is nog een raadsel mijn. Probeer het eens te raden! "Afgevallen klappers zonder gat (waar de vrucht aan de steel vast zat).» - Een kippenei!

3. «Naar boven zijn wortels, naar beneden zijn ....»- Een baard!

4. Er is nog weer een raadsel van me. Raad eens: "Er is een vrucht deze, valt ze naar beneden, zoekt men ze naar boven.» - Regen lekkende uit het dak.

5. Er is nog een raadsel. Zeg het eens: "Er is een vrucht, zij groeit ginds in het Maleische land.» Hoe heet ze? - De zon.

\section{$\mathrm{N}$ à n $\mathrm{g} \overline{\mathrm{a}}-\mathrm{n}$ à $\mathrm{n} \mathrm{g} \overline{\mathrm{a}}$.}

1. Aléng-aléng salatan, Moejoeb moealas-alasan, $\mathrm{Pa}^{\mathrm{s}}$ asò biloe ${ }^{s}$ si fěsang.

\section{Biloes rantjoeng bangkoeang}

Disoesoen $e^{s}$ éténg loean.

\section{Diamòtèn mès Padang} Mangabés ènèn plang.

3. Biloe ${ }^{5}$ rantjoeng bangkireng

Disoesoen è éténg asén.

Diamòtèn mès Singkil Mangabés bahōng gambir Balandjònè mèchawil.

4. Aléng-aléng toenggarò, Moejoeb moesafò-safò, $\mathrm{Pa}^{5}$ asò da $\mathrm{ka}^{\mathrm{s}}$ oewò Mamòti sira mè banò.

5. Majang-majang koerěsěh, Sa'bét mòn anmò ifěh, Sa bét an sèe-sèèh Mès dètas toematafěh.
Liedjes.

1. Komaan Zuidewind, blaas en doe zachtjes voortgaan, stuw voort het schip dat (ginds) aan komt (zeilen).

2. Het schip is scherp en van bangko-hout

gebouwd aan den oever van de rivier.

Men zeilde er mee naar Padang om te halen bonte kleeren.

3 . Het schip heeft een scherpen voorsteven en is van bangkirénghout gebouwd aan den oever der zee. Men zeilde er mee naar Singkil om tabak en gambir te halen en blandja om te huwen.

4. Kom ZuidOostewind, blaas zachtjes aan, dwing ..... dat zij zeilen naar land toe.

5. Kiekendief met bonte veeren, pak toch uw krabbenkostje, pak het eten zachtjes naar boven in den toematafěhboom. 
6. $\mathrm{Ka}^{\mathrm{s}}$ majang òj $\mathrm{ka}^{\mathrm{s}}$ majang, Sa'bét mòn $a^{5} \bar{o}$ oemabang Mè isè aj loean, Mangèna $^{5}$ biloe $^{5}$ si fěsang.

7. Toe moedò laja baoeng, Ngaja dètas liang soekoen,

Ngaja mangkarang soedoeng, Toefafanè mès boesoeng.

8. Biri'-biri' latitis,

Béré oemennggés!

Éta mengabés wés

È lěbang toeroehé.

9. $\mathrm{Ka}^{\text {s }}$ bòlěm,

Béré $a^{s} \bar{o}$ moeragam!

Samò taïla gěnggěm.

10. Aléng-aléng toenggarò Pamanggél barat dajò,

$\mathrm{Pa}^{\text {s asò }}$ mè Samadoeò, Mangabés salōntjōngmòh, Salōntjōng kèròh-hèrò.

11. Aléng-aléng salatan, Pamanggél barat silan,

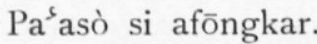

Niamòtèn mès Padang, Mangabés salōntjōng plang.

12. Nga sangaōn ifan' $\bar{o} h$, Nga soedoeis ${\text { soedoei }{ }^{\text {s }} \text { loemang }}^{s} \overline{0}$.

Ba ${ }^{5}$ dō oechitō-chitō.

Èněng masènoe oechitō, Sènoe ${ }^{s}$ bessang toean'ōh Tènè banòn Malajoe, Mangabé ba doe-ba doeng ${ }^{s} \bar{o} h$.
6. Zuster kiekendief o zusje kiekendief, pak toch mij mee in uw vlucht naar ginds naar de riviermonding, om te zien de komende schepen.

7. . . . .

hij zit op een tak van den broodboom,

Hij schikt een ruikertje bloemen, zijn zending naar de baai.

8. Vogel latitis, ge moet niet weenen!

Wij gaan water halen aan de put onder den toeroehéboom.

9. Zuster duif,

Ge moet mij niet grillig behandelen! Gelijkelijk kunnen wij beheeren.

10. Kom wind uit het ZuidOosten, roeper van den wind uit het Zuid-

Westen, voer ons naar Samadoeò, om te halen een broek voor u, een broek van batik-goed.

11. Komaan Zuidewind, roeper van den wind uit het Noord-Westen, drijf voort den vertrekkende.

Hij zeilt naar Padang om te halen een broek van bonte stof.

12. Ik heb een sirih-struikje, staande aan een hoek van mijn huis.

Maar ik pluk er niet van. Eerst later pluk ik ze, als dan komt mijn heer uit het maleische land, waar hij baadjes voor mij is gaan halen. 